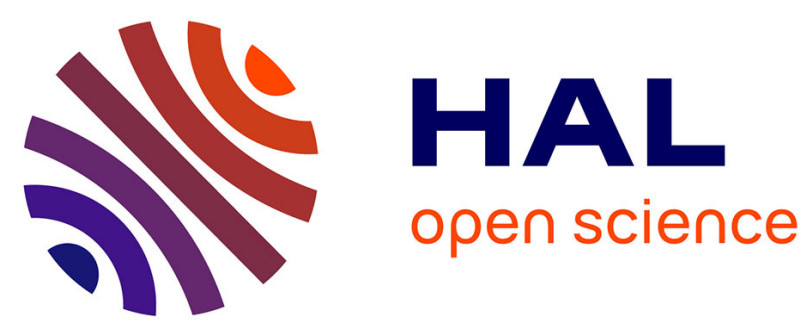

\title{
Holocene and Pleistocene fringing reef growth and the role of accommodation space and exposure to waves and currents (Bora Bora, Society Islands, French Polynesia)
}

Eberhard Gischler, J Harold Hudson, Marc Humblet, Juan Carlos Braga, Dominik Schmitt, Anja Isaack, Anton Eisenhauer, Gilbert Camoin

\section{To cite this version:}

Eberhard Gischler, J Harold Hudson, Marc Humblet, Juan Carlos Braga, Dominik Schmitt, et al.. Holocene and Pleistocene fringing reef growth and the role of accommodation space and exposure to waves and currents (Bora Bora, Society Islands, French Polynesia). Sedimentology, 2019, 10.1111/sed.12533 . hal-02386271

\section{HAL Id: hal-02386271 \\ https://hal.science/hal-02386271}

Submitted on 29 Nov 2019

HAL is a multi-disciplinary open access archive for the deposit and dissemination of scientific research documents, whether they are published or not. The documents may come from teaching and research institutions in France or abroad, or from public or private research centers.
L'archive ouverte pluridisciplinaire HAL, est destinée au dépôt et à la diffusion de documents scientifiques de niveau recherche, publiés ou non, émanant des établissements d'enseignement et de recherche français ou étrangers, des laboratoires publics ou privés. 
Article type : Original Article

\title{
Holocene and Pleistocene fringing reef growth and the role of accommodation space and exposure to waves and currents (Bora Bora, Society Islands, French Polynesia)
}

\author{
Eberhard Gischler ${ }^{\star}$, J. Harold Hudson ${ }^{\dagger}$, Marc Humblet $^{\ddagger}$, Juan Carlos Braga ${ }^{\S}$, \\ Dominik Schmitt $^{*}$, Anja Isaack*, Anton Eisenhauer ${ }^{\star}$ and Gilbert F. Camoin ${ }^{* *}$
}

*Institut für Geowissenschaften, Goethe-Universität, Altenhoeferallee 1, 60438 Frankfurt am Main, Germany (E-mail: gischler@em.uni-frankfurt.de)

${ }^{\dagger}$ ReefTech Inc., Miami, Florida 33143, USA

${ }^{\ddagger}$ Department of Earth and Planetary Sciences, Nagoya University, Nagoya 464-8601, Japan

${ }^{\S}$ Departamento de Estratigrafía y Paleontología, Universidad de Granada, 18002 Granada, Spain

IGEOMAR Helmholtz-Zentrum für Ozeanforschung, 24148 Kiel, Germany

*A Aix-Marseille Université, CNRS, IRD, Collège de France, CEREGE, Europôle

Méditerranéen de l'Arbois, BP 80, 13545 Aix-en-Provence Cedex 4, France

\section{Associate Editor - Giovanna Della Porta}

Short Title - Fringing reef growth, Bora Bora

This article has been accepted for publication and undergone full peer review but has not been through the copyediting, typesetting, pagination and proofreading process, which may lead to differences between this version and the Version of Record. Please cite this article as doi: $10.1111 /$ sed.12533

This article is protected by copyright. All rights reserved. 


\section{ABSTRACT}

Holocene fringing reef development around Bora Bora is controlled by variations in accommodation space (as a function of sea-level and antecedent topography) and exposure to waves and currents. Subsidence ranged from 0 to $0.11 \mathrm{~m} / \mathrm{kyr}$, and did not create significant accommodation space. A windward fringing reef started to grow $8.7 \mathrm{kyr} \mathrm{BP}$, retrograded towards the coast over a Pleistocene fringing reef until ca $6.0 \mathrm{kyr} \mathrm{BP}$, and then prograded towards the lagoon after sea-level had reached its present level. The retrograding portion of the reef is dominated by corals, calcareous algae and microbialite frameworks; the prograding portion is largely detrital. The reef is up to $13.5 \mathrm{~m}$ thick and accreted vertically with an average rate of $3.12 \mathrm{~m} / \mathrm{kyr}$. Lateral growth amounts to $13.3 \mathrm{~m} / \mathrm{kyr}$. Reef corals are dominated by an inner Pocillopora assemblage and an outer Acropora assemblage. Both assemblages comprise thick crusts of coralline algae. Palaeobathymetry suggest deposition in 0 to $10 \mathrm{~m}$ depth. An underlying Pleistocene fringing reef formed during the sea-level highstand of Marine Isotope Stage 5e, and is also characterized by the occurrence of corals, coralline algal crusts and microbialites. A previously investigated, leeward fringing reef started to form contemporaneously ( $8.78 \mathrm{kyr} \mathrm{BP}$ ), but is thicker (up to $20 \mathrm{~m}$ ) and solely prograded throughout the Holocene. A shallow Pocillopora assemblage and a deeper water Montipora assemblage were identified, but detrital facies dominate. At the Holocene reef base, only basalt was recovered. The Holocene windward-leeward differences are a consequence of less accommodation space on the eastern island side that eventually led to a more complex reef architecture. As a result of higher rates of exposure and flushing, reef framework on the windward island side is more abundant and experienced stronger cementation. In the Pleistocene, the environmental conditions on the leeward island side were presumably unfavourable for fringing reef growth.

Keywords Holocene, Pacific, Pleistocene, reef, U-series dating.

\section{INTRODUCTION}

Fringing reefs are the most common tropical, shallow-water reef type (Smithers, 2011). In the subsidence model of reef growth (Darwin, 1842), fringing reefs represent the basic type in the genetic sequence to barrier reefs and atolls. In uplift areas such as Barbados and the Huon Peninsula, fringing reefs have been used as important long-term gauges of late Quaternary sea-level change (Mesolella et al., 1969; Chappell et al., 1996). Fringing reefs

This article is protected by copyright. All rights reserved. 
are usually attached to the shoreline and their geomorphology and history appear to be comparatively simple. Despite this, Kennedy \& Woodroffe (2002) have shown that fringing reef growth and internal architecture may be rather complex. In their review, these authors discussed various growth models including vertical accretion, lateral accretion, episodic progradation, offshore accretion with lagoon formation and offshore rubble formation. Accommodation space appears to be of high significance as it dictates reef architecture. Changes in relative sea-level and antecedent topography, for example, slope angle and relief, in turn, control accommodation space.

Progradation due to a decrease in accommodation space appears to be a very common feature of fringing reef development. As relative sea-level rise both in the IndoPacific (transgressive-regressive) and the western Atlantic (transgressive) exhibits mid to late Holocene deceleration (Woodroffe and Webster, 2014; Camoin and Webster, 2015; and references therein), accommodation space has been decreasing in time and causing lateral reef accretion. Fringing reef development on the Queensland shelf behind the Great Barrier Reef has received significant attention (Kennedy and Woodroffe, 2002; Smithers et al., 2006; and references therein). Prograding types predominate (e.g. Hopley and Barnes, 1985; Johnson and Risk, 1987; Lewis et al., 2012) over those that started out in somewhat deeper water and caught up with sea-level (Chappell et al., 1983). Some of these reefs persisted during terrigenous input (e.g. Ryan et al., 2016). Smithers et al. (2006) and Hopley et al. (2007) have provided a structural classification of fringing reefs in the Great Barrier Reef province in which progradation plays a crucial role. In the Ryukyu Islands, Japan, examples of fringing reefs have been documented in detail, which exhibit progradation and downstepping due to tectonic uplift (Kan et al., 1997; Webster et al., 1998). In the northern Red Sea, Shaked et al. (2005) detected aggradation and subsequent lateral growth in Holocene fringing reefs. In the Indian Ocean, Mauritius fringing reefs first aggraded and then prograded (Montaggioni and Faure, 1997). Fringing reefs in the isolated barrier reef system of Mayotte (Indian Ocean) have apparently also prograded during the Holocene (Zinke et al., 2003). Braithwaite et al. (2000) have stressed the importance of storm redeposition during fringing reef accretion in the Seychelles. Likewise, Blanchon et al. $(1997,2017)$ have shown in Grand Cayman and eastern Yucatan fringing reefs (Caribbean Sea) that coral storm rubble has been transported landward over back reef areas and played an important role in reef accretion. In these Caribbean examples, fringing reefs have been retrograding significantly during the Holocene. In post-glacial fringing reef development that experienced high rates of sea-level rise following the last glacial maximum, retrogradation has been common also until modern level was reached (e.g. Cabioch et al., 1998).

This article is protected by copyright. All rights reserved. 
The classic study of Walther (1888; English translation by Ginsburg et al., 1994) along the north-western coast of the Red Sea has shown that antecedent topography may play a crucial role in fringing reef formation. Bedrock or terrigenous clastics form the basement of many fringing reefs as seen in examples on the Queensland shelf (e.g. Hopley et al., 2007; p. 191-232). In other instances, Pleistocene fringing reefs may act as Holocene fringing reef pedestals (Montaggioni and Faure, 1997; Kennedy and Woodroffe, 2002; and references therein). On the other hand, antecedent topography may also be largely masked by Holocene fringing reefs, as in the examples of Hanauma Bay, Oahu, Hawaii, and Galeta Point, Caribbean, Panama. Both of these studies represent the first time that core traverses were drilled across the reefs thereby allowing two-dimensional reconstructions. In Hanauma Bay, the fringing reef has been prograding during the Holocene (Easton and Olson, 1976). The fringing reef of Galeta Point exhibits aggradation and slight progradation of the marginal Acropora facies over the deeper water massive coral facies during the Holocene (Macintyre and Glynn, 1976).

Exposure to waves and currents is another potential environmental factor of fringing reef growth (e.g. Geister, 1977). However, there are only few studies in which windward and leeward differences in fringing reefs have been elaborated on. Cabioch et al. (1995) found that reef framework was more common in exposed than in protected sites on New Caledonia. Curiously, accretion rates in the fringing reefs studied were higher in more protected sites as compared to exposed sites. Hongo and Kayanne (2009) showed that a windward, robust Holocene reef framework contrasted with a leeward, detrital reef facies fringing Ishigaki Island in the Ryukyu Islands and found that the accretion rate was higher in the windward fringing reef.

This study presents results of a core study in which windward fringing reef growth on Bora Bora (Society Islands) is detailed and then compared with data from the leeward fringing reef of the same reef system in order to test to which extent variations in accommodation space and exposure to waves and currents exert control on reef development and architecture. Whereas the late Quaternary development of barrier and atoll reefs in French Polynesia has been the subject of detailed studies (e.g. Cabioch et al., 1999a; Camoin et al., 2001, 2012), fringing reefs have been largely neglected. The work by Montaggioni (1988) on fringing reefs of Tahiti and Moorea is based on one core each and revealed largely detrital facies and both keep-up and catch-up growth patterns, respectively. Fringing reef development on the leeward side of Bora Bora is characterized by both This article is protected by copyright. All rights reserved. 
coralgal-microbial and detrital facies, based on a core traverse (Gischler et al., 2016). The former study may be characterized as preliminary and the latter included only the leeward island side. In this study, fringing reef growth around Bora Bora will be compared with barrier reef accretion in the same reef system to obtain a comprehensive picture of the development of this isolated barrier reef system.

\section{STUDY AREA}

Bora Bora is located in the Society Archipelago (French Polynesia) in the central south Pacific Ocean. This archipelago comprises nine islands and five atolls (Fig. 1). Ages of the volcanic islands (4.3 to $0.3 \mathrm{Ma}$ ) increase from south-east to north-west and indicate a plate movement of $11 \mathrm{~cm} /$ year over the Society hotspot (Blais et al., 2000; Guillou et al., 2005). The volcanic islands of Bora Bora are 3.45 to $3.10 \mathrm{Ma}$ old based on radiometric (K/Ar) dating of basalts (Blais et al., 2000). The islands are composed of alkali basalt, rare hawaiites, intrusive gabbros and a volcanic breccia. The Baie de Povai is supposed to outline the former caldera (Fig. 2).

The climate of Bora Bora is characterized by a hot and wet season during the summer (November to April), and a colder and drier period in the winter (May to October) (Gabrié and Salvat, 1985). Trade winds blow from the north-eastern to south-eastern directions (Pirazzoli et al., 1985a). Eleven major cyclones have passed over the Society Islands from 1901 to 1968. Major storms Lisa, Reva and Veena passed over during 1982 and 1983 (Pirazzoli et al., 1985a). In February 2010, category 4 cyclone Oli made landfall on the Society Islands; tropical cyclone Niko passed over French Polynesia in January 2015. Annual average air temperature in French Polynesia ranges from $27^{\circ} \mathrm{C}$ in the north to $21^{\circ} \mathrm{C}$ in the south. Monthly air-temperature extremes in the Society Islands range from 24 to $28^{\circ} \mathrm{C}$ (Gabrié and Salvat, 1985). Annual precipitation in Bora Bora, measured from 1951 to 1961 (Guilcher et al., 1969), averages $2000 \mathrm{~mm} /$ year. Measurements of sea-surface temperatures in the lagoon ranged from 23.8 to $26.7^{\circ} \mathrm{C}$ in August 1963; salinity ranged from 36.7 to $36.9 \%$ during the same time period (Guilcher et al., 1969). The spring tidal range is up to $40 \mathrm{~cm}$ (Pirazzoli et al., 1985a).

This article is protected by copyright. All rights reserved. 
The volcanic island of Bora Bora covers ca $30 \mathrm{~km}^{2}$. The $32 \mathrm{~km}$ long coastline creates extensive bays and long peninsulas (Fig. 2). The highest point, Mount Otemanu, rises $727 \mathrm{~m}$ above sea-level. One ephemeral water course drains into Faanui Bay. The shoreline is almost completely lined by fringing reefs. The relief of the lagoon floor is high and there are six basins up to $40 \mathrm{~m}$ deep (Guilcher et al., 1969; Gabrié et al., 1994). Lagoonal patch reefs are largely lacking. One interruption in the barrier reef is up to $48 \mathrm{~m}$ deep and connects the lagoon with the open ocean. The barrier reef, including the reef crest and the extensive sand apron, is 1 to $2 \mathrm{~km}$ wide and covers some $70 \mathrm{~km}^{2}$. The reef crest consists largely of coralline algae (Porolithon) and the brown algae Turbinaria (Gabrié et al., 1994). Water depth on sand aprons does not exceed $3.5 \mathrm{~m}$. Coral patch reefs on the sand apron occur in the northeastern and eastern parts of Bora Bora, usually in the lee of narrow, shallow waterways (hoa) through elongated sand cays (motu). On the eastern, northern and north-western sides of Bora Bora, long and continuous motus are developed; they are interrupted by a few very shallow hoa. Lagoonal circulation is sustained by water entering the lagoon on the eastern reef and leaving through the western channel (Gabrié et al., 1994). On the ocean sides of the motus, coral rubble conglomerate, beachrock and elevated fossil reef terraces occur (Pirazzoli et al., 1985b; Pirazzoli and Montaggioni 1988a,b). The terraces are Holocene in age and are evidence of a higher than present Holocene sea-level (Rashid et al., 2014; Hallmann et al., 2018). Seaward of the reef crest, a well-developed spur and groove system can be found (Gabrié et al., 1994) which is characterized by a pavement of crustose coralline algae and few corals including Acropora and Pocillopora.

\section{METHODS}

Eight rotary cores were drilled on the windward island side of Bora Bora during May 2017 using a hydraulic drill attached to a tripod with wireline core barrel (Fig. 2). Barrel length was $1.5 \mathrm{~m}$. Geographic coordinates were recorded with GPS. Elevation was measured to mean sea-level (m.s.l.). The fringing reef traverse of three cores was drilled on the ca $80 \mathrm{~m}$ wide eastern fringing reef of Bora Bora with inter-core distances of ca $40 \mathrm{~m}$. Fringing reef cores include Puhia 1 (16²8.850'S; 151 $43.234^{\prime} \mathrm{W}$; drilled $0.3 \mathrm{~m}$ below m.s.I.), Puhia 2 (16²8.839'S; 15143.217'W; drilled $0.6 \mathrm{~m}$ below m.s.l.) and Puhia 3 (16²8.82.5'S; $151^{\circ} 43.197$ 'W; drilled $0.6 \mathrm{~m}$ below m.s.I.) (Fig. 3). Fringing reef core recovery ranged from 0 to $89 \%$ and averaged 22 to $63 \%$; recovery decreased from the shore towards the lagoon (Table 1). In addition, two core traverses of three and two cores, respectively, were drilled on the barrier reef of Motu Tofari and Motu Ome (Fig. 2). Cores include Tofari 1 (16 $29.636^{\prime} \mathrm{S}$; $151^{\circ} 41.812^{\prime} \mathrm{W}$; drilled $1 \mathrm{~m}$ above m.s.I.), Tofari 2 (16²9.652'S; 1514‥797'W; drilled 0.45

This article is protected by copyright. All rights reserved. 
below m.s.I.) and Tofari 3 (16²9.652'S: $151^{\circ} 41.849$ 'W; drilled $0.4 \mathrm{~m}$ above m.s.I.), Ome 1 $\left(16^{\circ} 27.084^{\prime} \mathrm{S} ; 1^{\circ} 1^{\circ} 43.685^{\prime} \mathrm{W}\right.$; drilled at m.s.I.) and Ome $2\left(16^{\circ} 27.091^{\prime} \mathrm{S} ; 1^{\prime} 1^{\circ} 43.698^{\prime} \mathrm{W}\right.$; drilled at m.s.I.). Barrier reef core recovery ranges from 21 to $43 \%$ in individual cores and averages $27.3 \%$ (Table 1). Depths of samples in cores including error ranges were calculated based on recovery in individual core barrels.

In the laboratory, cores were cut with an angle grinder and analysed with regard to sedimentology including diagenesis, systematics and geochronology. Thirty-five thin sections from samples taken from cores (16 fringing reef; 19 barrier reef samples) were qualitatively studied under a Leica DM 2500 M polarizing microscope (Leica, Wetzlar, Germany). Subsamples were powdered and relative amounts of carbonate minerals measured by X-ray diffraction (XRD) using a PANalytical X'Pert Pro diffractometer (Malvern Panalytical, Malvern, UK), following the method Milliman (1974). The same method was used to assess the aragonite content of corals selected for age dating (see below).

Corals in cores were identified using the standard publications of Wallace (1999), Veron (2000) and the guide of Humblet et al. (2015). The taxonomic nomenclature of scleractinian corals include recent modifications by Huang et al. (2014) in the family Merulinidae. Corals were identified at the lowest taxonomic level possible. Morphogroups were defined when several species in the same genus could not be distinguished (for example, Acropora gr. humilis). Coral colonies described as massive are $5 \mathrm{~cm}$ in thickness or more. The width of coral branches was measured and they were categorized as fine $(<1.0$ $\mathrm{cm})$, medium $(1.0$ to $1.5 \mathrm{~cm})$, or robust $(>1.5 \mathrm{~cm})$.

Coralline algae were identified in thin sections relying on standard descriptions. This study used the generic classification scheme proposed by Rösler et al. (2016) and Cargnano et al. (2018) for the order Corallinales. The palaeodepths inferred from coralline algal assemblages were derived from the published distributions of living members of the identified taxa in the Pacific Ocean (Adey et al., 1982; Cabioch et al., 1999b; Payri et al., 2000; Dechnik et al., 2017). The thickness of coralline algal crusts was measured. The occurrences of vermetids and the encrusting foraminifer Homotrema rubrum were noted.

This article is protected by copyright. All rights reserved. 
Twenty-eight uranium-series measurements of coral ages (13 fringing reef; 15 barrier reef samples) were made following standard procedures. For U/Th dating, corals with no indications of early diagenesis and an aragonite content of $>97 \%$ were selected. The three most aragonite-rich Pleistocene corals had aragonite contents ranging from 87 to $93 \%$ and were also included. Separation of uranium and thorium from the sample matrix was done using Eichrom-UTEVA resin following the methods of Fietzke et al. (2005). Determination of uranium and thorium isotope ratios were done at GEOMAR, Kiel, using a Thermo Fisher Neptune multi-ion-counting inductively coupled plasma mass spectrometer (MC-ICP-MS) (Thermo Fisher Scientific, Waltham, MA, USA) as described by Fietzke et al. (2005). For isotope dilution measurements, a combined ${ }^{233} \mathrm{U} /{ }^{236} \mathrm{U} /{ }^{229} \mathrm{Th}$ spike was used. Stock solutions were calibrated for concentration using NIST-SRM 3164 (U) and NIST-SRM 3159 (Th) as combi-spike, calibrated against CRM-145 uranium standard solution (formerly NBL-112A) for uranium isotope composition and against a secular equilibrium standard (HU-1, uranium ore solution) for the precise determination of ${ }^{230} \mathrm{Th} /{ }^{234} \mathrm{U}$ activity ratios. In clean room laboratories at GEOMAR, Kiel, usually whole-procedure blank values of this kind of samples were measured between $0.5 \mathrm{pg}$ and $1.0 \mathrm{pg}$ for thorium and between $10 \mathrm{pg}$ and $20 \mathrm{pg}$ for uranium. Both values are in the range typical of this method and the laboratory (Fietzke et al., 2005). Based on the ${ }^{230} \mathrm{Th} /{ }^{232} \mathrm{Th}$ and ${ }^{234} \mathrm{U} /{ }^{238} \mathrm{U}$ ratios, ages were calculated using the uranium and thorium half-lives of Cheng et al. (2000).

\section{RESULTS}

\section{Fringing reef}

The three cores recovered reefal successions ranging in thickness from 9.25 to $13.1 \mathrm{~m}$ in a lagoonward direction (Fig. 4). The reef limestones are underlain by basalt. In cores Puhia 1 and Puhia 2, a Holocene reef superimposes a Pleistocene reef. In core Puhia 3, the entire reef limestone succession is Holocene in age (Fig. 4).

\section{Holocene}

The Holocene fringing reef is 3.6 to $13.1 \mathrm{~m}$ thick. Thickness significantly increases lagoonward. It consists of coral-rich sections, crusts of coralline algae, coralgal sections, microbialite and unconsolidated sand and rubble (Fig. 4). Coralgal sections are very common in all cores and reach thicknesses of up to $4 \mathrm{~m}$ (Fig. 5A to D). Microbialite sections contain both structureless and laminated textures; they are as thick as $20 \mathrm{~cm}$, with an 
average thickness of $3.5 \mathrm{~cm}$ (Fig. 5E). Coral successions get as thick as several decimetres. Fourteen coral taxa have been identified (Table S1), and two coralgal assemblages may be distinguished, namely Acropora and Pocillopora assemblages (Fig. 4). The Acropora assemblage contains medium to robust-sized branches of acroporids and thick crusts of the algae Porolithon onkodes. The second assemblage is dominated by Pocillopora and also comprises thick crusts of $P$. onkodes. Crust thickness amounts to several centimetres. At the base of core Puhia 3, rhodoliths with large coral nuclei and thin coralline algal covers mainly composed of Hydrolithon boergesenii are found (Fig. 5F). Recovered coralline algal crusts may get as long as $1.5 \mathrm{~m}$ (for example, in core Puhia 2) because they grew vertically, presumably on the sides of coral framework (Fig. 5G). The vertical crusts are dominated by laminar, contorted growths of Mesophyllum, Lithophyllum and Harveylithon, as well as Peyssonneliaceans (Table S2). Some 20 algal taxa have been identified (Table S2). In core Puhia 3, a $6 \mathrm{~m}$ thick section at the top of the core consists of unconsolidated sand and rubble. Small amounts of millimetre-sized to centimetre-sized fragments of basalt occur at the middle and basal sections of Puhia 2 and at the base of core Puhia 3. Carbonate phases encountered in XRD of bulk samples include $55.6 \%$ aragonite, $44.1 \%$ high-magnesium calcite and $0.3 \%$ low-magnesium calcite on average (Table 2 ). The variation is large; however, aragonite and high-magnesium calcite predominate and low-magnesium calcite is rare. Marine cements are not abundant and include aragonite needle (acicular), botryoidal and peloidal high-magnesium calcite cements (Fig. 6A to $\mathrm{C}$ ). Acicular aragonite crystals reach $150 \mu \mathrm{m}$ in length, and botryoidal crystals are up to $400 \mu \mathrm{m}$ long. Peloids in the peloidal cement are 30 to $45 \mu \mathrm{m}$ and surrounded by clear equant crystals $<10 \mu \mathrm{m}$ in diameter. All Holocene U-series ages obtained are reliable based on aragonite content and

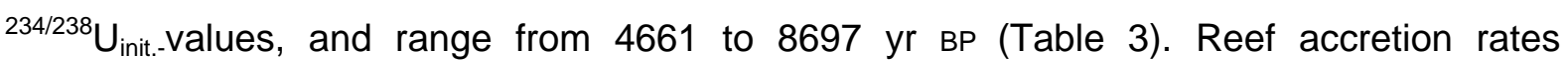
calculated between dated reef intervals in core range from 0.74 to $5.82 \mathrm{~m} / \mathrm{kyr}$ with an average value of $3.12 \mathrm{~m} / \mathrm{kyr}$ (Table 4). Accretion rates appear to generally decrease up core.

\section{Pleistocene}

The underlying Pleistocene fringing reef is 3.7 to $5.6 \mathrm{~m}$ thick (Fig. 4). In contrast to the Holocene reef, thickness of the Pleistocene reef decreases lagoonward. The Pleistocene reef consists of sections of coral, coralline algal crusts, coralgal sections and microbialite (Fig. 7A to D). At the top of the Pleistocene reef, reddish-brown stains are visible. In core Puhia 2, a $50 \mathrm{~cm}$ thick breccia with fragments of coral, coralline algae including rhodoliths and small (coarse sand to fine pebble) basalt grains occur (Fig. 7E). Coral sections get as thick as $0.5 \mathrm{~m}$. Five coral taxa have been identified (Table S1) and there are two coral 
assemblages. The Pocillopora assemblage with thick $P$. onkodes crusts, and a Porites assemblage with encrusting to massive Porites colonies and $P$. onkodes crusts (Fig. 4). Recovered sections with coralline algal crusts may exceed $1 \mathrm{~m}$ in thickness, and like in the Holocene, layering is vertical. These crusts are mainly composed of laminar, contorted thalli of Mesophyllum, Lithophyllum and Harveylithon (Fig. 7D). Twelve algal taxa have been identified (Table S2). Microbialite crusts are usually structureless and a few centimetres thick. In cores Puhia 1 and 2, coarse sand-sized to small pebble-sized fragments of basalt occur throughout the Pleistocene reef (Fig. 7A to $\mathrm{C}$ ). In general, the Pleistocene core sections are somewhat darker as compared with the Holocene sections and have a greyish hue. Carbonate phases identified in bulk samples using XRD comprise $60.3 \%$ aragonite, $6.4 \%$ high-magnesium calcite and $33.3 \%$ low-magnesium calcite on average (Table 2 ). In contrast to the Holocene reef section, low-magnesium calcite contents are high and highmagnesium calcite contents are low. Blocky low-magnesium calcite cement with crystal sizes of 80 to $120 \mu \mathrm{m}$ is encountered both in inter-particle porosity and within coral and coralline algal components (Fig. $6 \mathrm{D}$ to F). Aragonite and high-magnesium calcite components are in many cases neomorphosed and dissolved portions replaced by blocky low-magnesium calcite crystals. Based on the comparatively low aragonite contents and the elevated ${ }^{234 / 238} U_{\text {init. }}$-values, the $U$-series ages from Pleistocene corals are not considered reliable. In core Puhia 1, the dates are moderately reliable and range from 141.67 to 144.02 kyr BP (Table 3). The calculated accretion rate, which has to be treated with caution, would amount to $2.41 \mathrm{~m} / \mathrm{kyr}$ (Table 4), and is in the same range as the Holocene rates. The dates from core Puhia 2 range from 167.12 to $169.02 \mathrm{kyr}$ BP, but are characterized as being unreliable.

\section{Barrier reef}

Unlike the fringing reef cores, none of the windward barrier reef cores reached the Holocene reef base due to drill problems caused by abundant unconsolidated sand (Fig. 8). Core thickness ranges from $6 \mathrm{~m}$ to a little more than $20 \mathrm{~m}$. Species of Acropora with mediumsized to robust-sized branches predominate. Eighteen coral taxa have been identified (Table S3). Thick crusts of Porolithon onkodes are common, indicating shallow $(<10 \mathrm{~m})$, highenergy depositional environments. At the tops of three seaward cores, vermetids and Homotrema rubrum are found in addition to robust acroporids and thick Porolithon crusts, suggesting a shallower palaeo-water depth of $<6 \mathrm{~m}$. Eighteen coralline algal taxa were identified (Table S4). Among coralline algal crusts, the encrusting foraminifer Carpentaria sp. occurs rarely. Other than in the fringing reef cores, microbialite crusts are very rare and thin,

This article is protected by copyright. All rights reserved. 
and were found only in the middle part of Tofari 1 and at the base of Tofari 2. At the top of core Ome 2, a $3 \mathrm{~m}$ thick section with very well-cemented rudstone was recovered, most probably massive beachrock. Marine cements are not abundant, and include aragonite needles, high-magnesium calcite peloidal and microcrystalline cements. Reliable U-series age data in barrier reef cores range from 6849 to $5035 \mathrm{yr}$ BP at core bases and from 5168 to $2620 \mathrm{yr}$ BP at core tops (Table 3; Fig. 8). Barrier reef accretion rates are from 2.9 to 20.4 $\mathrm{m} / \mathrm{kyr}$ and average $7.02 \mathrm{~m} / \mathrm{kyr}$ (Table 4). However, most values are in the range of 4 to 5 $\mathrm{m} / \mathrm{kyr}$; the high value of $>20 \mathrm{~m} / \mathrm{kyr}$ has to be treated with caution because it comes from a core section with relatively low recovery (Ome 2).

\section{DISCUSSION}

\section{Holocene fringing reef development}

The Holocene Puhia fringing reef exhibits a zonation with a landward Pocillopora and lagoonward Acropora coralgal assemblage. While both assemblages presumably occurred in shallow water ( 0 to $10 \mathrm{~m}$ ), as additionally indicated by the commonly found thick crusts of Porolithon onkodes, vermetids and Homotrema; the acroporid corals are characteristic of a more open setting and the pocilloporids of a somewhat more protected environment (Abbey et al., 2011). The curious thick, vertically oriented coralline algal crusts in the Puhia cores are dominated by taxa that typically occur in poorly illuminated settings, which usually occur in deeper reef areas or in shaded habitats, such as crevices or caves. In Puhia, they probably grew on the shaded sides of coral colonies and reef framework. In the leeward fringing reef, the landward core Faanui 1 was also characterized by a Pocillopora assemblage in the upper core section. The lower portion (>7.8 kyr BP) of the core consisted of a deeper water (10 to $20 \mathrm{~m}$ ) assemblage dominated by laminar Montipora and a basal sandy facies (Gischler et al., 2016). Microbialite crusts usually occur in core sections older than approximately $6 \mathrm{kyr}$ BP. This is in accordance with the findings in the other cores in Bora Bora (Gischler et al., 2016) and in Tahiti, and has been explained by changes in environmental parameters such as light and energy, nutrients and alkalinity (Camoin et al., 1999; Seard et al., 2011; Heindel et al., 2012; Riding et al., 2014). The youngest, progradational section of the windward Puhia fringing reef is detrital and largely composed of unconsolidated sand and rubble. Likewise, the upper prograding section of the leeward Faanui fringing reef consists of unconsolidated material.

This article is protected by copyright. All rights reserved. 
The Holocene Puhia fringing reef has largely kept up with sea-level rise, which provided ample accommodation space. Both the new age data from the windward and that from the leeward fringing reefs plot within the upper part of the data obtained from Bora Bora (Fig. 9). Whereas the windward Puhia fringing reef exhibits retrogradation followed by progradation, the leeward Faanui fringing reef apparently solely prograded throughout the Holocene. The reason for this difference is not entirely clear, however, because of the existing Pleistocene reef topography, Holocene reef growth may have been forced to initiate more lagoonward and migrated onto the fossil reef as sea-level was rising. On the leeward island side, the early nearshore reef initiation $8.7 \mathrm{kyr}$ BP in the leeward Faanui fringing reef was probably due to the greater accommodation space. An older portion of the Faanui fringing reef might exist at the base of the most seaward core FAA 2, but unfortunately this section was not recovered (Fig. 10). The fringing reefs in the geomorphologically similar Mayotte barrier reef system are also composed of massive and branched corals and bioclastic sand and gravel, established ca $8 \mathrm{kyr}$ BP, and reach thicknesses of up to $10 \mathrm{~m}$, but it is not entirely clear whether they accreted in keep-up or catch-up modes (Zinke et al., 2003). Many fringing reefs in other regions such as the Great Barrier Reef province are dominated by progradation (Kennedy and Woodroffe, 2002; Smithers et al., 2006; and references therein). These reefs initiated usually 1.5 to $2.0 \mathrm{kyr}$ earlier and their overall thickness of 5 to $10 \mathrm{~m}$ (Smithers et al., 2006) is significantly lower than the south Pacific examples studied here. Still, in the Great Barrier Reef, fringing reefs of type A of Smithers et al. (2006) and Hopley et al. (2007) also show initial retrogradation and subsequent progradation, like the Puhia fringing reef in Bora Bora. Reef type A occurs in the narrow, rocky foreshore, is rather rare in the Great Barrier Reef province, and the history has not been detailed by drilling as yet according to these authors. The fringing reefs along the north-western coast of Australia (western Indian Ocean) analysed by Twiggs and Collins (2010) also exhibit initial aggradation, retrogradation and then progradation during the Holocene. During the transition from retrogradation to progradation, reef growth supposedly declined likely due to enhanced run-off and turbidity. The retrograding to prograding reef architecture may be interpreted as a direct response to the mid to late Holocene decreasing rate of rise of sea-level and the coeval decrease in accommodation space. The vertical accretion rate of the windward fringing reef in Bora Bora amounts to $3.12 \mathrm{~m} / \mathrm{kyr}$ on average and is somewhat lower than the reported rate of the leeward fringing reef of $5.65 \mathrm{~m} / \mathrm{kyr}$ (Gischler et al., 2016). This observation is similar to the data of Cabioch et al. (1998) in New Caledonia where accretion rates of the leeward fringing reef exceed those of the windward fringing reef. The lateral accretion of both windward and leeward fringing reefs in Bora Bora is estimated to some $80 \mathrm{~m}$ in $6 \mathrm{kyr}$, i.e. $13.3 \mathrm{~m} / \mathrm{kyr}$. Recovery in the windward fringing reef $(42.9 \%)$ is significantly higher as compared to the leeward fringing reef $(18.1 \%)$, which is

This article is protected by copyright. All rights reserved. 
interpreted to be a consequence of both the larger amount of reefal framework facies and the stronger early submarine cementation, which is commonly higher in more exposed reefs. Both Cabioch et al. (1995) and Hongo and Kayanne (2009) in their windward-leeward comparisons of New Caledonia and Ishigaki Island, Japan, respectively, found framework facies to be more common on windward fringing reefs as compared to leeward fringing reefs where detrital facies were more abundant. Higher exposure to waves and currents at windward positions leads to stronger flushing of pore spaces with seawater that is supersaturated with regard to calcium carbonate and, hence, results in more pervasive cementation in these settings (Marshall and Davies, 1981; Aissaoui and Purser, 1985; Gischler and Lomando, 1997).

\section{Pleistocene fringing reef development}

The geochronology data, the occurrence and the elevation of the underlying Pleistocene fringing reef recovered in cores Puhia 1 and 2 makes formation during Marine Isotope Stage (MIS) 5e very likely. The age data ranging from 141 to $169 \mathrm{kyr}$ BP are not reliable; however, they may be explained by the loss of uranium during light meteoric diagenesis. Using an average age of $125 \mathrm{kyr}$ BP for MIS 5e and a $6 \mathrm{~m}$ higher than present sea-level (Hearty et al., 2007; Dutton et al., 2015), the subsidence rate of the island of Bora Bora may be estimated to 0 to $0.08 \mathrm{~m} / \mathrm{kyr}$ (core Puhia 1) and to 0.03 to $0.11 \mathrm{~m} / \mathrm{kyr}$ (core Puhia 2). These subsidence ranges compare well with the estimated range of 0.05 to $0.14 \mathrm{~m} / \mathrm{kyr}$ based on the Bora Bora barrier reef core TEV 1 (Gischler et al., 2016). Based on the value of $0.11 \mathrm{~m} / \mathrm{kyr}$, maximum subsidence during Holocene fringing reef accretion since $8.8 \mathrm{kyr}$ BP amounts to $0.97 \mathrm{~m}$. Thus, in contrast to sea-level rise, subsidence has provided only a minor portion of accommodation space for reef accretion.

Like its Holocene counterpart, the Pleistocene fringing reef shows a zonation with a landward Pocillopora assemblage (core Puhia 1) and a lagoonward Porites coralgal assemblage (core Puhia 2). Both of these assemblages contain thick crusts of $P$. onkodes and vermetids, and are considered to have been deposited in shallow water (0 to $10 \mathrm{~m})$. It is not entirely clear as to why there is a Porites-dominated assemblage seaward of the Pocillopora-dominated assemblage, which is a zonation different from that observed in the overlying Holocene fringing reef. Porites is considered as being indicative of either deeper water or more turbid conditions (Abbey et al., 2011). Siliciclastic input was presumably somewhat greater in the more landward setting of core Puhia 1. However, small, sand-sized

This article is protected by copyright. All rights reserved. 
basalt fragments occur throughout both Pleistocene core sections of Puhia 1 and 2. This is an interesting difference compared to the Holocene core sections where terrigenous input is largely missing. Temperatures are considered higher during MIS $5 \mathrm{e}$ in the tropics in general and in the south Pacific (e.g. Cortese et al., 2013), and it could be speculated that at the same time somewhat wetter conditions during MIS 5e as compared to the Holocene led to more erosion and terrigenous runoff during precipitation events. The complete lack of a Pleistocene fringing reef at the leeward island location might also be a consequence of stronger runoff. The only watercourse on the island drains into Faanui Bay and might have rendered conditions too turbid for reef development during MIS $5 \mathrm{e}$ around this location. Based on the much weaker Holocene cementation on the leeward side, it could also be speculated that a leeward Pleistocene reef has been eroded during subaerial exposure after MIS 5e. Apart from $P$. onkodes crusts, thick vertically oriented coralline algal crusts are found also in the Pleistocene fringing reef. Again, taxa indicative of shaded environments dominate and suggest growth on the sides of corals and the reef framework. Microbialite crusts occur in the Pleistocene core sections as well, but for unknown reasons they are not as abundant as in the Holocene. This observation suggests that apart from nutrient input and runoff from a basaltic hinterland additional environmental factors must be responsible for abundant microbialite formation. In accordance with the data compiled by Riding et al. (2014), it could possibly be explained by low alkalinity at the peak of MIS 5e.

\section{Fringing versus barrier reef growth}

For Darwin (1842), fringing reefs were the initial reef type in the genetic sequence of fringing, barrier and atoll reefs, controlled by subsidence of volcanic islands. As elegant as this model is, changes in relative sea-level, especially during the Quaternary high-amplitude sea-level variability, as well as other environmental factors were not considered (e.g. Purdy, 1974; Montaggioni, 2005; Purdy and Winterer, 2006; Toomey et al., 2013). 'Fringing to barrier' reef transitions as predicted by the subsidence model have not been documented convincingly as yet. Blanchon et al. (2014) suggested for Tahiti a fringing to barrier reef transformation during 14.0 to $12.3 \mathrm{kyr}$ BP. These authors proposed that a transition to fastgrowing acroporids boosted barrier-reef accretion when the fringing reef was isolated from the coast and from terrigenous influx. However, the fringing to barrier transition was not recovered and could not be dated exactly. Likewise, there are no age data of the top of the underlying Pleistocene platform. In general, it is largely unknown when and how the modern fringing reefs around the island of Tahiti came into existence and developed, because they have not been investigated systematically by drilling thus far. Previous drilling in Bora Bora

This article is protected by copyright. All rights reserved. 
has shown that the leeward Holocene barrier reef likely grew on top of a late Pleistocene barrier reef, not on a fringing reef (Gischler et al., 2016). There, the Pleistocene reef was encountered $30 \mathrm{~m}$ below modern sea-level, and the adjacent Pleistocene lagoon deposits at $-40 \mathrm{~m}$. A comparable Pleistocene barrier reef geomorphology is likely for the windward barrier reef even though its top has not been reached during the present study. The maximum lagoon depths behind the windward Tofari and Ome drill sites reach 31 to $34 \mathrm{~m}$, and adding another $10 \mathrm{~m}$ of Holocene lagoonal sediment thickness (Gischler et al., 2016; Isaack et al., 2016) places the Pleistocene lagoon floor some $40 \mathrm{~m}$ below modern sea-level, as on the leeward island side. It remains to be seen whether or not the windward barrier reef thickness also amounts to $30 \mathrm{~m}$.

This study and preceding drill projects on Bora Bora (Gischler et al., 2016; Isaack et al., 2016) have shown that Holocene fringing and barrier reefs developed contemporaneously in the same reef system. Comparable results were obtained elsewhere, for example, in the Mayotte (Zinke et al., 2003), Chuuk (Truk) and the New Caldonian barrier reef systems (Purdy and Winterer, 2006, and references therein). It is noteworthy in this context that the fringing reef of Bora Bora apparently developed in water depths somewhat shallower as compared to the nearby barrier reef during ca 9 to $5 \mathrm{kyr}$ BP. Both windward and leeward fringing reef age data plot consistently several metres above the barrier reef data of Bora Bora and Tahiti before $5 \mathrm{kyr}$ BP (Fig. 9). However, it remains somewhat enigmatic as to why this palaeobathymetrical difference developed between fringing and barrier reefs during the early to mid Holocene. Both the leeward and the windward barrier reef of Bora Bora is dominated by an Acropora coral assemblage with medium-sized to robust-sized branches and thick crusts of Porolithon onkodes. Both the leeward and the windward barrier reef exhibit progradation (Gischler et al., 2016). A limitation of the palaeobathymetrical interpretation is the fact that the resolution of the palaeo-depth does not go below $10 \mathrm{~m}$, and is similar in the Acropora assemblage, which dominates at the barrier reef, and the Pocillopora assemblages, that is common at the fringing reef. Only in the late Holocene, the abundant occurrences of vermetids and Homotrema together with robust acroporids allow for a somewhat more precise palaeobathymetrical interpretation at the barrier reef locations.

This article is protected by copyright. All rights reserved. 


\section{CONCLUSIONS}

Holocene windward and leeward fringing reefs, located in the isolated barrier-reef system of Bora Bora, are more or less of the same age but show considerable differences with regard to composition and architecture. The windward fringing reef retrograded and then prograded during the Holocene. The reef exhibits zonation with a landward Pocillopora and a lagoonward Acropora coralgal assemblage. Sand and rubble is common in the prograding phase only. The leeward fringing reef simply prograded during the Holocene. Pocillopora and Montipora coralgal assemblages occur; sand and rubble are very common. Fringing reef consolidation is much stronger on the windward as compared to the leeward side of Bora Bora. These differences are most likely to be the result of differences in available accommodation space and exposure to waves and currents. Windward-leeward differences must have been even greater during the late Pleistocene as reef framework occurs only on the windward island side. Environmental conditions, i.e. elevated input of terrigenous material due to stronger runoff during Marine Isotope Stage $5 \mathrm{e}$, were supposedly deleterious for reef development at the leeward location. For reasons which are not entirely clear, fringing reefs probably grew in somewhat shallower water during the early-mid Holocene as compared to the nearby barrier reef. Comparisons with fringing reefs in other regions, especially the Great Barrier Reef region, where this reef type has been studied intensively, reveals both similarities and differences. While progradation is a common architectural element in many fringing reefs as it is in Bora Bora, initial retrogradation and subsequent progradation has only been observed and studied in a limited number of examples and requires further studies.

\section{ACKNOWLEDGMENTS}

We thank the Deutsche Forschungsgemeinschaft (DFG) who has been funding the research in Bora Bora (Gi 222/23-2). Maiarii Teriipaia, Rick Hunter, and Philip Teriipaia assisted us during field-work. Gabriela Meyer also helped during drilling, operated the GPS, and acted as French interpreter. Gérard Bion supported us in various ways. Dr. Marie-Joseph Juen tended to repeatedly occurring minor to moderate injuries of the drill team. The mayor of Bora Bora and the Ministère du Logement, des Affaires Foncières, de l'Économie Numérique et de l'Artisanat (Papeete) kindly issued research permits. Two anonymous journal reviewers and the associate editor made very helpful comments that improved this paper.

This article is protected by copyright. All rights reserved. 


\section{REFERENCES}

Abbey, E., Webster, J.M., Braga, J.C., Sugihara, K., Wallace, C., Iryu, Y., Potts, D., Done, T., Camoin, G. and Seard, C. (2011) Variation in deglacial coralgal assemblages and their paleoenvironmental significance: IODP Expedition 310, "Tahiti Sea Level". Global Planet. Change, 76, 1-15.

Adey, W.H., Townsend, R.A. and Boykins, W.T. (1982) The crustose coralline algae (Rhodophyta: Corallinaceae) of the Hawaiian Islands. Smiths. Contr. Mar. Sci., 15, 1-74.

Aissaoui, D.M. and Purser, B.H. (1985) Reef diagenesis: cementation at Mururoa Atoll (French Polynesia). Proc. 5th Int. Coral Reef Symp., 3, 257-262.

Bard, E., Hamelin, B., Arnold, M., Montaggioni, L.F., Cabioch, G., Faure, G. and Rougerie, F. (1996) Deglacial sea-level record from Tahiti corals and the timing of global meltwater discharge. Nature, 382, 241-244.

Blais, S., Guille, G., Guillou, H., Chauvel, C., Maury, R.C. and Caroff, M. (2000) Géologie, géochimie et géochronologie de l'île de Bora Bora (Société, Polynésie Française). Acad. Sci. (Paris) C.R. Sci. Terre Planètes, 331, 579-585.

Blanchon, P., Granados-Corea, M., Abbey, E., Braga, J.C., Braithwaite, C., Kennedy, D.M., Spencer, T., Webster, J.M. and Woodroffe, C.D. (2014) Postglacial fringing-reef to barrier-reef conversion on Tahiti links Darwin's reef types. Sci. Rep., 4, 4997.

Blanchon, P., Jones, B. and Kalbfleisch, W. (1997) Anatomy of a fringing reef around Grand Cayman island: storm rubble, not coral framework. J. Sed. Res., 67,1-16.

Blanchon, P., Richards, S., Bernal, J.P., Cerdeira-Estrada, S., Ibarra, M.S., CoronaMartinez, L. and Martell-Dubois, R. (2017) Retrograde accretion of a Caribbean fringing reef controlled by hurricanes and sea-level rise. Frontiers Earth Sci., 5. Available at: doi:10.3389/feart.2017.00078

Braithwaite, C., Montaggioni, L.F., Camoin, G.F., Dalmasso, H., Dullo, W.C. and Mangini, A. (2000) Origins and development of Holocene coral reefs: a revisited model based on reef boreholes in the Seychelles, Indian Ocean. Int. J. Earth Sci., 89, 431-445.

Cabioch, G., Camoin, G.F. and Montaggioni, L.F. (1999a) Postglacial growth history of a French Polynesian barrier reef tract, Tahiti, central Pacific. Sedimentology, 46, 985-1000.

Cabioch, G., Montaggioni, L.F., Faure, G. and Ribaud-Laurenti, A. (1999b) Reef coralgal assemblages as recorders of paleobathymetry and sea level changes in the Indo-Pacific

This article is protected by copyright. All rights reserved. 
province. Quat. Sci. Rev., 18, 1681-1695.

Cabioch, G., Montaggioni, L.F. and Faure, G. (1995) Holocene initiation and development of New Caledonian fringing reefs, SW Pacific. Coral Reefs, 14, 131-140.

Cabioch, G., Taylor, F.W., Récy, J., Edwards, R.L., Gray, S.C., Faure, G., Burr, G.S. and Corrège, T. (1998) Environmental and tectonic influence on growth and internal structure of a fringing reef at Tasmaloum (SW Espiritu Santo, New Hebrides island arc, SW Pacific). In: Reefs and carbonate platforms in the Pacific and Indian Oceans (Eds G.F. Camoin and P.J. Davies), IAS Spec. Publ., 25, 261-277.

Camoin, G.F., Ebren, P., Eisenhauer, A., Bard, E. and Faure, G. (2001) A 300,000 years record of sea-level changes, Mururoa atoll (French Polynesia). Palaeogeogr. Palaeoclimatol. Palaeoecol., 175, 325-341.

Camoin, G.F., Gautret, P., Montaggioni, L.F. and Cabioch, G. (1999) Nature and environmental significance of microbialites in Quaternary reefs: the Tahiti paradox. Sed. Geol., 126, 271-304.

Camoin, G.F., Seard, C., Deschamps, P., Webster, J.M., Abbey, E., Braga, J.C., Iryu, Y., Durand, N., Bard, E., Hamelin, B., Yokoyama, Y., Thomas, A.L., Henderson, G.M. and Doussoulliez, P. (2012) Reef response to sea-level and environmental changes during the last deglaciation: Integrated Ocean Drilling Program Expedition 310, Tahiti Sea Level. Geology, 40, 643-646.

Camoin, G.F. and Webster, J.M. (2015) Coral reef response to Quaternary sea-level and environmental changes: state of the science. Sedimentology, 62, 401-428.

Caragnano, A., Foetisch, A., Maneveldt, G.W., Millet, L., Liu, L.C., Lin, S.M., Rodondi, G. and Payri, C.E. (2018) Revision of Corallinaceae (Corallinales, Rhodophyta): recognizing Dawsoniolithon gen. nov., Parvicellularium gen. nov. and Chamberlainoideae subfam. nov. containing Chamberlainium gen. nov. and Pneophyllum. Journal of Phycology, 54, 391-409. Available at: doi: 10.1111/jpy.12644.

Chappell, J., Chivas, A., Wallensky, E., Polach, H.A. and Aharon, P. (1983) Holocene palaeo-environmental changes, central to north Great Barrier Reef inner zone. BMR J. Austral. Geol. Geoph., 8, 223-235.

Chappell, J., Omura, A., Esat, T., McCulloch, M., Pandolfi, J., Ota, Y. and Pillans, B. (1996) Reconciliation of late Quaternary sea levels derived from coral terraces at Huon Peninsula with deep sea oxygen isotope records. Earth Planet. Sci. Lett., 141, 227-236.

This article is protected by copyright. All rights reserved. 
Cheng, H., Edwards, R., Hoff, J., Gallup, C., Richards, D. and Asmerom, Y. (2000) The half-lives of uranium-234 and thorium-230. Chem. Geol., 169, 17-33.

Cortese, G., Dunbar, G.B., Carter, L., Scott, G., Bostock, H., Bowen, M., Crundwell, M., Hayward, B.W., Howard, W., Martinez, J.I., Moy, A., Neil, H., Sabaa, A. and Sturm, A. (2013) Southwest Pacific Ocean response to a warmer world: insights from marine isotope stage 5e. Paleoceanogr., 28, 585-598.

Darwin, C.R. (1842) The Structure and Distribution of Coral Reefs. Smith Elder, London, $214 \mathrm{pp}$.

Dechnik, B., Webster, J.M., Webb, G.E., Braga, J.C., Zhao, J., Duce, S. and Sadler, J. (2017) The evolution of the Great Barrier Reef during the last interglacial period. Global Planet. Change, 149, 53-71.

Dutton, A., Carlson, A.E., Long, A.J., Milne, G.A., Clark, P.U., DeConto, R., Horton, B.P., Rahmstorf, S. and Raymo, M.E. (2015) Sea-level rise due to polar ice-sheet mass loss during past warm periods. Science, 349, aaa4019-1.

Easton, W.H. and Olson, E.A. (1976) Radiocarbon profile of Hanauma Reef, Oahu, Hawaii. Geol. Soc. Amer. Bull., 87, 711-719.

Fietzke, J., Liebetrau, V., Eisenhauer, A. and Dullo, W.C. (2005) Determination of uranium isotope ratios by multi-static MIC-ICP-MS, method and implementation for precise U- and Th-series isotope measurements. J. Anal. Atomic Spectr., 20, 395-401.

Gabrié, C. and Salvat, B. (1985) General features of French Polynesian islands and their coral reefs. Proc. 5th Int. Coral Reef Symp., 1, 3-15.

Gabrié, C., Planes, S., Baldwin, J., Bonvallot, C., Chauvet, C., Vernaudon, Y., Payri, C., and Galzin, R. (1994) Study of the coral reefs of Bora-Bora (Society archipelago, French Polynesia) for the development of a conservation and management plan. Ocean \& Coastal Manag., 25, 189-216.

Geister, J. (1977) The influence of wave exposure on the ecological zonation of Caribbean coral reefs. Proc. 3rd Int. Coral Reef Symp., 1, 23-29.

Ginsburg, R.N., Gischler, E. and Schlager, W. (1994) Johannes Walther on reefs. Pioneering concepts of biogeology 1885 - 1910. Geological Milestones, 2, 141 pp.

Gischler, E. (2011) Sedimentary facies of Bora Bora, Darwin's type barrier reef (Society Islands, south Pacific): the unexpected occurrence of non-skeletal grains. J. Sed. Res., 81, 1-17.

This article is protected by copyright. All rights reserved. 
Gischler, E., Hudson, J.H., Humblet, M., Braga, J.C., Eisenhauer, A., Isaack, A., Anselmetti, F.S. and Camoin, G.F. (2016) Late Quaternary barrier and fringing reef development of Bora Bora (Society Islands, south Pacific): first subsurface data from the Darwin type barrier-reef system. Sedimentology, 63, 1522-1549.

Gischler, E. and Lomando, A.J. (1997) Holocene cemented beach deposits in Belize. Sed. Geol., 110, 277-297.

Guilcher, A., Berthois, L., Doumenge, F., Michel, A., Saint-Requier, A. and Arnold, R. (1969) Les récifs et lagons coralliens de Mopelia et de Bora-Bora (îles de la Société). Mém. Orstrom., 38, 103 pp.

Guillou, D., Maury, R.C., Blais, S., Cotten, J., Legendre, C., Guille, G. and Caroff, M. (2005) Age progression along the Society hotspot chain (French Polynesia) based on new unspiked K-Ar ages. Soc. Géol. France Bull., 176, 135-150.

Hallmann, N., Camoin, G., Eisenhauer, A., Botella, A., Milne, G.A., Vella, C., Samankassou, E., Pothin, V., Dussouillez, P., Fleury, J. and Fietzke, J. (2018) Ice volume and climate changes from a 6000 year sea-level record in French Polynesia. Nature Comm., 9, 285. Available at: doi: 10.1038/s41467-017-02695-7.

Hearty, P.J., Hollin, J.T., Neumann, A.C., O'Leary, M.J. and McCulloch, M. (2007) Global sea-level fluctuations during the last interglacial (MIS 5e). Quat. Sci. Rev., 26, 2090-2112.

Heindel, K., Birgel, D., Brunner, B., Thiel, V., Westphal, H., Ziegenbalg, S.B., Gischler, E., Cabioch, G. and Peckmann, J. (2012) Post-glacial microbialite formation in coral reefs in the Pacific Ocean, Caribbean, and Indian Ocean. Chem. Geol., 304-305, 117130.

Hongo, C. and Kayanne, H. (2009) Holocene coral reef development under windward and leeward locations at Ishigaki Island, Ryukyu Islands, Japan. Sed. Geol., 214, 62-73.

Hopley, D. and Barnes, R. (1985) Structure and development of a windward fringing reef, Orpheus Island, Palm Group, Great Barrier Reef. Proc. 5th Int. Coral Reef Symp., 1, 141 146.

Hopley, D., Smithers, S.G. and Parnell, K.E. (2007) The Geomorphology of the Great Barrier Reef: Development, Diversity, and Change. Cambridge University Press, Cambridge, $532 \mathrm{pp}$. 
Huang, D., Benzoni, F., Fukami, H., Knowlton, N., Smith, N. D. and Budd, A. F. (2014) Taxonomic classification of the reef coral families Merulinidae, Montastraeidae, and Diploastraeidae (Cnidaria: Anthozoa: Scleractinia). Zool. J. Linnean Soc., 171, 277-355.

Humblet, M., Hongo, C. and Sugihara, K. (2015) An identification guide to some major Quaternary fossil reef-building coral genera (Acropora, Isopora, Montipora, and Porites). Island Arc, 24, 16-30.

Isaack, A., Gischler, E., Hudson, J.H., Anselmetti, F.A., Lohner, A., Garbode, E. and Camoin, G. (2016) A new model evaluating sediment dynamics throughout the Holocene: insights from a mixed carbonate-siliciclastic lagoon (Bora Bora, Society Islands, French Polynesia, South Pacific). Sed. Geol., 343, 99-118.

Johnson, D.P. and Risk, M.J. (1987) Fringing reef growth on a terrigenous mud foundation, Fantome Island, central Great Barrier Reef, Australia. Sedimentology, 34, 275-287.

Kan, H., Hori, N., Kawana, T., Kaigara, T. and Ichikawa, K. (1997) The evolution of a Holocene fringing reef and island: reefal environmental sequence and sea level change in Tonaki Island, the central Ryukyus. Atoll Res. Bull., 443, 1-20.

Kennedy, D.M. and Woodroffe, C.D. (2002) Fringing reef growth and morphology: a review. Earth-Sci. Rev., 57, 255-277.

Lewis, S.E., Wüst, R.A.J., Webster, J.M., Shields, G.A., Renema, W., Lough, J.M. and Jacobsen, G. (2012) Development of an inshore fringing coral reef using textural, compositional and stratigraphic data from Magnetic Island, Great Barrier Reef, Australia. Mar. Geol., 299, 18-32.

Macintyre, I.G. and Glynn, P.W. (1976) Evolution of modern Caribbean fringing reef, Galeta Point, Panama. Amer. Assoc. Petrol. Geol. Bull., 60, 1054-1072.

Marshall, J.F. and Davies, P.J. (1981) Submarine lithification on windward reef slopes: Capricorn-Bunker group, southern Great Barrier Reef. J. Sed. Petrol, 51, 953-960.

Mesolella, K.J., Matthews, R.K., Broecker, W.S. and Thurber, D.L. (1969) The astronomical theory of climatic change: Barbados data. J. Geol., 77, 250-274.

Milliman, J.D. (1974) Marine Carbonates. Recent Sedimentary Carbonates. Part 1. New York, Springer, $375 \mathrm{pp}$.

Montaggioni, L.F. (1988) Holocene reef growth history in mid-plate high volcanic islands. Proc. 6th Int. Coral Reef Symp., 3, 455-460.

This article is protected by copyright. All rights reserved. 
Montaggioni, L.F. (2005) History of Indo-Pacific coral reef systems since the last glaciation: development patterns and controlling factors. Earth-Sci. Rev., 71, 1-75.

Montaggioni, L.F. and Faure, G. (1997) Response of reef coral communities to sea-level rise: a Holocene model from Mauritius (western Indian Ocean). Sedimentology, 44, 10531070.

Payri, C.E. (1997) Hydrolithon reinboldii rhodolith distribution, growth and carbon production of a French Polynesian reef. Proc. 8th Int. Coral Reef Symp., 1, 755-760.

Payri, C.E., N'yeurt, A.d.R. and Orempuller, J. (2000) Algae of French Polynesia (Algues de Polynésie Française). Au Vent des îles Ed., Tahiti, 320 pp.

Pirazzoli, P.A. and Montaggioni, L.F. (1988a) Holocene sea-level changes in French Polynesia. Palaeogeogr. Palaeoclimatol. Palaeoecol. 68, 153-175.

Pirazzoli, P.A. and Montaggioni, L.F. (1988b) The $7000 \mathrm{yr}$ sea level curve in French Polynesia: geodynamic implication for mid-plate volcanic islands. Proc. 6th Int. Coral Reef Symp., 3, 467-477.

Pirazzoli, P.A., Brousse, R., Delibras, G., Montaggioni, L.F., Sachet, M.H., Salvat, B. and Sinoto, Y.H. (1985a) Leeward islands, Maupiti, Tupai, Bora Bora, Huahine, Society archipelago. Proc. 5th Int. Coral Reef Symp., 1, 17-72.

Pirazzoli, P.A., Montaggioni, L.F., Delibrias, G., Faure, G. and Salvat, B. (1985b) Late Holocene sea-level changes in the Society Islands and in the northwest Tuamotu Atolls. Proc. 5th Int. Coral Reef Symp., 3, 131-136.

Purdy, E.G. (1974) Reef configurations: cause and effect, In: Reefs in Time and Space (Ed. L.F. Laporte), SEPM Spec. Publ., 18, 9-76.

Purdy, E.G. and Winterer, E.L. (2006) Contradicting barrier reef relationships for Darwin's evolution of reef types. Int. J. Earth Sci., 95, 143-167.

Rashid, R., Eisenhauer, A., Stocchi, P., Liebetrau, V., Fietzke, J., Rüggeberg, A. and Dullo, W.C. (2014) Constraining mid to late Holocene relative sea level change in the southern equatorial Pacific Ocean relative to the Society Islands, French Polynesia. Geochem. Geophys. Geosyst., 15, 2601-2615.

Reimer, P.J. and 30 others (2013) IntCal13 and Marine13 radiocarbon age calibration curves 0-50,000 years cal BP. Radiocarbon, 55, 1869-1887.

This article is protected by copyright. All rights reserved. 
Riding, R., Liang, L. and Braga, J.C. (2014) Millennial-scale ocean acidification and late Quaternary decline of cryptic bacterial crusts in tropical reefs. Geobiology, 12, 387-405.

Rösler, A., Perfectti, F., Pena, V. and Braga, J.C. (2016) Phylogenetic relationships of corallinaceae (Corallinales, Rhodophyta): taxonomic implications for reef-building corallines. J. Phycol., 52, 412-431.

Ryan, E.J., Smithers, S.G., Lewis, S.E., Clark, T.R. and Zhao, J.X. (2016) Chronostratigraphy of Bramston Reef reveals a long-term record of fringing reef growth under muddy conditions in the central Great Barrier Reef. Palaeogeogr. Palaeoecol. Palaeoclimatol., 441, 734-747.

Seard, C., Camoin, G., Yokoyama, Y., Matsuzaki, H., Durand, N., Bard, E., Sepulcre, S. and Deschamps, P. (2011) Microbialite development patterns in the last deglacial reefs from Tahiti (French Polynesia; IODP Expedition \#310): implications on reef framework architecture. Mar. Geol., 279, 63-86.

Shaked, Y., Lazar, B., Marco, S., Stein, M., Tchernov, D. and Agnon, A. (2005) Evolution of fringing reefs: space and time constraints from the Gulf of Aqaba. Coral Reefs, 24, 165-172.

Smithers, S.G. (2011) Fringing reefs. In: Encyclopedia of Modern Coral Reefs (Ed. D. Hopley), pp. 430-445. Springer, The Netherlands.

Smithers, S.G., Hopley, D. and Parnell, K.E. (2006) Fringing and nearshore coral reefs of the Great Barrier Reef: episodic Holocene development and future prospects. J. Coast. Res., 22, 175-187.

Toomey, M., Ashton, A.D. and Perron, J.T. (2013) Profiles of ocean island coral reefs controlled by sea-level history and carbonate accumulation rates. Geology, 41, 731-734.

Twiggs, E.J. and Collins, L.B. (2010) Development and demise of a fringing coral reef during Holocene environmental change, eastern Ningaloo Reef, western Australia. Mar. Geol., 275, 20-36.

Veron, J.E.N. (2000) Corals of the World. Australian Institute of Marine Science and CRR Qld Pty Ltd, Townsville, Australia, 3 volumes.

Wallace, C.C. (1999) Staghorn corals of the world. Museum of Tropical Queensland; CSIRO Publishing, Collingwood, Australia, 421 pp.

This article is protected by copyright. All rights reserved. 
Walther, J. (1888) Die Korallenriffe der Sinaihalbinsel. Geologische und biologische Beobachtungen. Abh. math.-phys. Cl. Kgl. Sächs. Ges. Wiss., 24, 439-505.

Webster, J.M., Davies, P.J. and Konishi, K. (1998) Model of fringing reef development in response to progressive sea level fall over the last 7000 years - (Kikai-jima, Ryukyu Islands, Japan). Coral Reefs, 17, 289-308.

Woodroffe, C.D. and Webster, J.M. (2014) Coral reefs and sea-level change. Mar. Geol., 352, 248-267.

Zinke, J., Reijmer, J.J.G., Thomassin, B., Dullo, W.C., Grootes, P.M. and Erlenkeuser, H. (2003): Postglacial flooding history of the Mayotte lagoon (Comoro archipelago, SW Indian Ocean). Mar. Geol., 194, 181-196.

\section{FIGURE CAPTIONS}

Fig. 1. Map of the Society Archipelago, French Polynesia, including Bora Bora. After Gabrié and Salvat (1985).

Fig. 2. Map of Bora Bora including drill sites of this study (Puhia 1 to 3; Tofari 1 to 3; Ome 1 to 2), and other drill locations of previous studies (Gischler et al., 2016).

Fig. 3. Satellite image (from Google Earth) that shows the exact position of the fringing reef cores Puhia 1 to 3 on the eastern island side.

Fig. 4. Core logs across the Puhia fringing reef, eastern side of Bora Bora; including Useries age data and indicating the distribution of coralgal assemblages. Note that coralline algal crusts and microbialite crusts occur throughout the cores, and are therefore not indicated on the logs.

This article is protected by copyright. All rights reserved. 
Fig. 5. Selected core photographs from the Holocene sections. (A) Merulinid coral (Astrea curta?) and coralline algal crust; the latter associated with Homotrema and vermetids. Puhia 1, -0.75 m. (B) Branched corals (Pocillopora), coralline algae and microbialite infill. Puhia 1, $2.5 \mathrm{~m}$. (C) Thick coralline algal crust with vermetids; coral (Porites?) at top. Puhia 1, $-1.75 \mathrm{~m}$. (D) Acropora humilis, thin coralline algal crust, and boring mollusc. Puhia 2, -2.5 m. (E) Thick coralline algal crust with Homotrema and microbialite. Puhia 2, -4.25 m. (F) Rhodoliths at the base of Holocene section. Puhia 3, $-13.5 \mathrm{~m}$. (G) Coralline algal crust with vertical layering. Puhia 2, $-5.0 \mathrm{~m}$.

Fig. 6. Selected thin section micrographs from the cores. Scale on all photographs is 500 $\mu \mathrm{m}$. (A) Aragonite needle (acicular) cement and high-magnesium calcite peloidal cement in coralline algal framework cavity. Holocene, core Puhia 1, -2.25 m. (B) Intra-skeletal porosity in coral is lined by aragonite needle and high-magnesium calcite peloidal cements. Holocene, core Puhia 2, $-1.5 \mathrm{~m}$. (C) Botryoidal aragonite cement in core Puhia 2, $-4.5 \mathrm{~m}$. Holocene. (D) Blocky low-magnesium calcite cement among coral fragments. Coral in the upper part of photograph shows centres of calcification. Pleistocene, core Puhia 2, $-8.0 \mathrm{~m}$. $(\mathrm{E})$ and $(\mathrm{F})$ Diagenetically altered coralline algal crust with blocky low-magnesium calcite cement. Note the development of a 'structure grumuleuse' or 'clotted micrite' in (E). Pleistocene, core Puhia 2, $-10.5 \mathrm{~m}$.

Fig. 7. Selected core photographs from the Pleistocene sections. (A) Coralline algal crust, coral fragments and basalt pieces at top of Pleistocene reef. Puhia 1, $-3.75 \mathrm{~m}$. (B) Pocillopora embedded in brownish sediment; few lithoclasts and basalt pieces. Puhia 1, $4.25 \mathrm{~m}$. (C) Branched coral (Pocillopora) and basalt fragments. Puhia 1, -5.8 m. (D) Crust of coralline algae with vertical layering; contains siliciclastic sediment in lower part. Puhia 2, $8.75 \mathrm{~m}$. (E) Breccia with carbonate and basalt fragments as well as altered branched coral (Acropora) at top of Pleistocene reef section. Puhia 2, -8.0 m. (F) Altered acroporid corals fragments. Puhia 2, $-9.5 \mathrm{~m}$.

Fig. 8. Core log transects across the windward barrier reef; including U-series age data and indicating the distribution of coralgal assemblages. (A) Motu Tofari core traverse. (B) Motu Ome core traverse. Note that coralline algal crusts occur throughout the cores, and therefore are not indicated. Microbialite crusts are very rare.

This article is protected by copyright. All rights reserved. 
Fig. 9. Uranium-series age data from windward Puhia fringing reef plotted together with existing Holocene sea-level data from Bora Bora and Tahiti, Society Islands. Age data from leeward Faanui fringing reef are plotted separately. Age data from Gischler (2011), Rashid et al. (2014) and Hallmann et al. (2018) are from elevated, late Holocene reef terraces on Bora Bora. ${ }^{14} \mathrm{C}$ age data from Bard et al. (1996) have been calibrated (Reimer et al., 2013). Bora Bora sea-level curve is from Gischler et al. (2016).

Fig. 10. Reconstruction of reef development in the Holocene including occurrences of coral assemblages and reef history (isochrones). Upper diagram; Puhia fringing reef on the windward island side originated in somewhat deeper water and then retrograded at first, before prograding later on. Lower diagram; Faanui fringing reef on the leeward island side shows only progradation throughout the Holocene (based on data from Gischler et al., 2016). Numbers at isochrones are ages in kyr BP. Sections are not vertically exaggerated.

\section{TABLE CAPTIONS}

Table 1. Recovery in the fringing and barrier reef cores.

Table 2. Results of X-ray diffraction (XRD) analyses of bulk samples as well as of corals and mollusc shells in cores.

Table 3. Uranium-series dates from fringing and barrier reef cores.

Table 4. Corrected elevations of samples including calculated accretion rates.

This article is protected by copyright. All rights reserved. 


\section{SUPPLEMENTARY TABLE CAPTIONS}

Table S1. Corals identified in Puhia cores, including information on coralline algal crust thickness and occurrence of vermetids and Homotrema. $\mathrm{BR}=$ branching; $\mathrm{COR}=$ corymbose; $\mathrm{DIG}=$ digitate; $\mathrm{EN}=$ encrusting; $\mathrm{F}-\mathrm{BR}$ = fine branching; $\mathrm{M}=$ massive; $\mathrm{M}-\mathrm{BR}=$ medium branching; $\mathrm{PL}=$ platy; $\mathrm{R}-\mathrm{BR}=$ robust branching; $\mathrm{STAG}=$ staghorn; $\mathrm{TAB}=$ tabular; IS = in situ; ISX = not in situ.

Table S2. Occurrence of coralline algae and Halimeda in thin-section along the fringing reef cores.

Table S3. Corals identified in barrier reef cores, including information on coralline algal crust thickness and occurrence of vermetids and Homotrema. $\mathrm{BR}=$ branching; $\mathrm{COR}=$ corymbose; $\mathrm{DIG}=$ digitate; $\mathrm{EN}=$ encrusting; $\mathrm{F}-\mathrm{BR}=$ fine branching; $\mathrm{M}=$ massive; $\mathrm{M}-\mathrm{BR}=$ medium branching; $\mathrm{PL}=$ platy; $\mathrm{R}-\mathrm{BR}=$ robust branching; $\mathrm{STAG}=$ staghorn; $\mathrm{TAB}=$ tabular; IS = in situ; ISX = not in situ.

Table S4. Occurrence of coralline algae and Halimeda in thin-section along the barrier reef cores.

This article is protected by copyright. All rights reserved. 


\begin{tabular}{|c|c|c|c|c|c|}
\hline Core, barrel & recovery & recovery & Core, barrel & recovery & recovery \\
\hline & $(\mathrm{m})$ & (\%) & & $(\mathrm{m})$ & (\%) \\
\hline fringing reef & & & barrier reef & & \\
\hline Puhia 1 & & & Tofari 1 & & \\
\hline barrel 1 & 0.78 & 52.0 & barrel 1 & 0.60 & 40.0 \\
\hline barrel 2 & 1.33 & 88.7 & barrel 2 & 0.60 & 40.0 \\
\hline barrel 3 & 0.82 & 54.7 & barrel 3 & 0.27 & 18.0 \\
\hline barrel 4 & 1.10 & 73.3 & barrel 4 & 0.33 & 22.0 \\
\hline barrel 5 & 0.78 & 52.0 & barrel 5 & 0.27 & 18.0 \\
\hline barrel 6 & 0.83 & 55.3 & barrel 6 & 0.23 & 15.3 \\
\hline barrel 7 & 0.93 & 62.0 & barrel 7 & 0.11 & 7.3 \\
\hline mean & 0.94 & 62.6 & mean & 0.34 & 23.0 \\
\hline Puhia 2 & & & Tofari 2 & & \\
\hline barrel 1 & 0.25 & 16.7 & barrel 1 & 0.80 & 53.3 \\
\hline barrel 2 & 0.95 & 63.3 & barrel 2 & 0.92 & 61.3 \\
\hline barrel 3 & 0.95 & 63.3 & barrel 3 & 0.43 & 28.7 \\
\hline barrel 4 & 1.12 & 74.7 & barrel 4 & 0.54 & 36.0 \\
\hline barrel 5 & 0.57 & 38.0 & barrel 5 & 0.33 & 22.0 \\
\hline barrel 6 & 0.98 & 65.3 & barrel 6 & 0.22 & 14.7 \\
\hline barrel 7 & 0.77 & 51.3 & barrel 7 & 0.38 & 25.3 \\
\hline barrel 8 & 0.68 & 45.3 & barrel 8 & 0.22 & 14.7 \\
\hline \multirow[t]{2}{*}{ mean } & 0.78 & 52.2 & barrel 9 & 0.23 & 15.3 \\
\hline & & & barrel 10 & 0.47 & 31.3 \\
\hline Puhia 3 & & & barrel 11 & 0.14 & 9.3 \\
\hline barrel 1 & 0.00 & 0.0 & mean & 0.43 & 28.4 \\
\hline barrel 2 & 0.00 & 0.0 & & & \\
\hline barrel 3 & 0.00 & 0.0 & Tofari 3 & & \\
\hline barrel 4 & 0.00 & 0.0 & barrel 1 & 0.55 & 36.7 \\
\hline barrel 5 & 0.36 & 24.0 & barrel 2 & 0.36 & 24.0 \\
\hline barrel 6 & 0.57 & 38.0 & barrel 3 & 0.42 & 28.0 \\
\hline barrel 7 & 0.50 & 33.3 & barrel 4 & 0.59 & 39.3 \\
\hline barrel 8 & 0.73 & 48.7 & barrel 5 & 0.13 & 8.7 \\
\hline barrel 9 & 0.42 & 28.0 & mean & 0.41 & 27.3 \\
\hline barrel 10 & 0.65 & 43.3 & & & \\
\hline \multirow[t]{2}{*}{ mean } & 0.32 & 21.5 & Ome 1 & & \\
\hline & & & barrel 1 & 1.42 & 94.7 \\
\hline \multirow[t]{26}{*}{ total mean } & 0.64 & 42.9 & barrel 2 & 0.65 & 43.3 \\
\hline & & & barrel 3 & 0.68 & 45.3 \\
\hline & & & barrel 4 & 0.70 & 46.7 \\
\hline & & & barrel 5 & 0.26 & 17.3 \\
\hline & & & barrel 6 & 0.41 & 27.3 \\
\hline & & & barrel 7 & 0.41 & 27.3 \\
\hline & & & mean & 0.65 & 43.1 \\
\hline & & & & & \\
\hline & & & Ome 2 & & \\
\hline & & & barrel 1 & 0.65 & 43.3 \\
\hline & & & barrel 2 & 0.95 & 63.3 \\
\hline & & & barrel 3 & 0.52 & 34.7 \\
\hline & & & barrel 4 & 0.50 & 33.3 \\
\hline & & & barrel 5 & 0.22 & 14.7 \\
\hline & & & barrel 6 & 0.48 & 32.0 \\
\hline & & & barrel 7 & 0.00 & 0.0 \\
\hline & & & barrel 8 & 0.22 & 14.7 \\
\hline & & & barrel 9 & 0.17 & 11.3 \\
\hline & & & barrel 10 & 0.00 & 0.0 \\
\hline & & & barrel 11 & 0.20 & 13.3 \\
\hline & & & barrel 12 & 0.04 & 2.7 \\
\hline & & & barrel 13 & 0.27 & 18.0 \\
\hline & & & barrel 14 & 0.27 & 18.0 \\
\hline & & & mean & 0.32 & 21.4 \\
\hline & & & & & \\
\hline & & & total mean & 0.41 & 27.3 \\
\hline & & & & & \\
\hline
\end{tabular}

This article is protected by copyright. All rights reserved. 


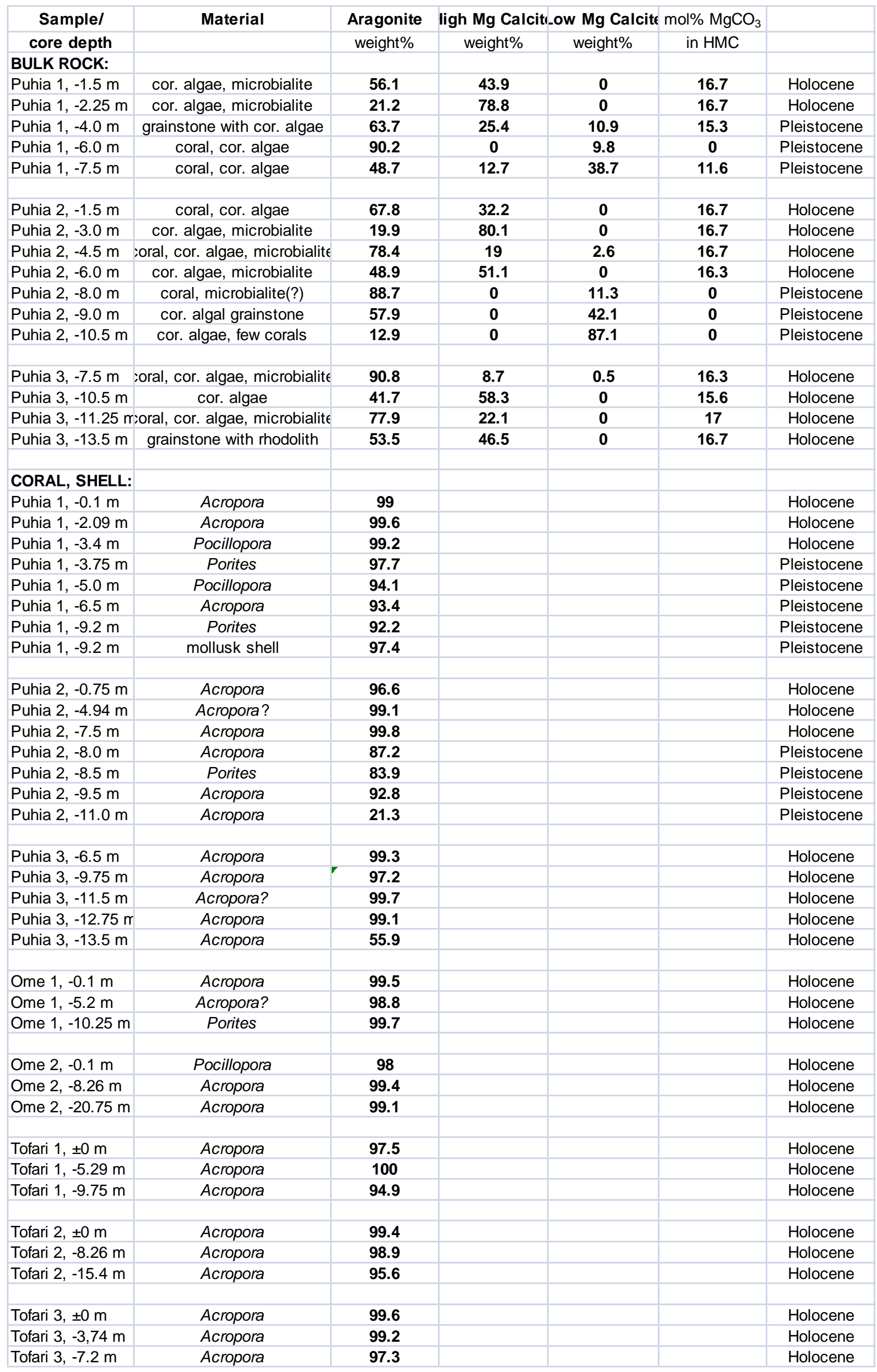

This article is protected by copyright. All rights reserved. 


\begin{tabular}{|c|c|c|c|c|c|c|c|c|c|c|c|c|c|c|c|c|c|c|c|c|}
\hline sample & coral a & $\begin{array}{c}\text { aragonite } \\
\%\end{array}$ & $\begin{array}{c}\text { Age } \\
\text { ky }\end{array}$ & $\begin{array}{c} \pm \\
\text { ky }\end{array}$ & $\begin{array}{l}\text { U238 } \\
\text { ppm }\end{array}$ & $\begin{array}{c} \pm \\
\text { ppm }\end{array}$ & \begin{tabular}{|c|} 
Th232 \\
ppb
\end{tabular} & $\underset{\mathrm{ppb}}{ \pm}$ & $\begin{array}{c}\text { Th230 } \\
\text { ppt }\end{array}$ & $\begin{array}{c} \pm \\
\text { ppt }\end{array}$ & $\begin{array}{c}\text { Th230/Th23: } \\
\text { dpm/dpm }\end{array}$ & $\frac{ \pm}{\mathrm{dpm} / \mathrm{dpm}}$ & $\begin{array}{l}\text { U238/Th232 } \\
\text { dpm/dpm }\end{array}$ & $\frac{ \pm}{\mathrm{dpm} / \mathrm{dpm}}$ & $\begin{array}{l}\text { Th230/U238 } \\
\text { dpm/dpm }\end{array}$ & $\frac{ \pm}{d p m / d p m}$ & $\begin{array}{l}\text { U234/U238 } \\
\text { n dpm/dpm }\end{array}$ & $\stackrel{ \pm}{\mathrm{dpm} / \mathrm{dpm}}$ & $\begin{array}{l}\text { U234/U238 } \\
n \quad \text { initial }\end{array}$ & $8 \underset{\mathrm{dpm} / \mathrm{dpm}}{ \pm}$ \\
\hline & & & & & & & & & & & & & & & & & & & dpm/dpm & \\
\hline Puhia $1,-0.10 \mathrm{~m}$ & Acropora & 99.0 & 5.116 & 0.027 & 4.8605 & 0.0078 & 1.232 & 0.002 & 4.187 & 0 & 639.03 & 2.48 & 12127.04 & 37.34 & 0.052 & 0.0001 & 1.148 & 0.004 & 1.15 & 0.004 \\
\hline Puhia $1,-2.10 \mathrm{~m}$ & Acropora & 99.6 & 7.356 & 0.037 & 3.0764 & 0.0037 & 5.243 & 0.018 & 3.7673 & 0.0005 & 134.33 & 0.49 & 1793.1 & 6.68 & 0.074 & 0.0001 & 1.142 & 0.004 & 1.145 & 0.004 \\
\hline Puhia 1, $-3.40 \mathrm{mF}$ & Pocillopora & 99.2 & 7.607 & 0.050 & 2.1802 & 0.0033 & 7.46 & 0.017 & 2.772 & 0 & 69.54 & 0.26 & 893.9 & 2.59 & 0.0768 & 0.0001 & 1.143 & 0.004 & 1.146 & 0.004 \\
\hline Puhia 1, $-3.75 \mathrm{~m}$ & Porites & 97.7 & 141.673 & 1.432 & 2.7259 & 0.0034 & 14.873 & 0.168 & 36.648 & 0.001 & 460.95 & 5.38 & 560.42 & 6.38 & .8121 & 0.001 & 1.11 & 0.004 & 1.164 & 0.005 \\
\hline Puhia $1,-9.20 \mathrm{~m}$ & Porites & 92.2 & 144.025 & 1.655 & 2.3392 & 0.0032 & 33.58 & 0.722 & 31.854 & 0.001 & 177.39 & 3.85 & 212.94 & 4.59 & 0.8225 & 0.0011 & 1.112 & 0.004 & 1.169 & 0.005 \\
\hline Puhia 2, $-0.75 \mathrm{~m}$ & Acropora & 96.6 & 4.661 & 0.026 & 5.4036 & 0.0082 & 7.249 & 0.038 & 4.322 & 0 & 57 & 0.68 & 09 & 12.67 & 183 & 0.0001 & 162 & .004 & 1.164 & 0.004 \\
\hline Puhia 2, $-4.95 \mathrm{~m}$ & Acropora? & 99.1 & 7.554 & 0.043 & 2.8399 & 0.0058 & 2.468 & 0.006 & 3.5613 & .0005 & 78 & 0.8 & & 12.24 & 757 & 0.0002 & 142 & 0.004 & 1.145 & 0.004 \\
\hline Puhia 2, $-7.50 \mathrm{~m}$ & Acropora & 99.8 & 8.374 & 0.042 & 3.0324 & 0.0051 & 2.524 & 0.003 & 4.208 & 0 & 312.52 & 1.05 & 3681.59 & 9.03 & 838 & 0.0001 & 145 & 0.004 & 1.148 & 0.004 \\
\hline Puhia 2, $-8.00 \mathrm{~m}$ & Acropora & 87.2 & 169.019 & 1.892 & 2.7992 & 0.0039 & 4.912 & 0.016 & 41.646 & 0.001 & 1587.53 & 7.14 & 1744.19 & 6.54 & 0.8987 & 0.0013 & 1.128 & 0.003 & 1.207 & 0.004 \\
\hline Puhia 2, $-9.50 \mathrm{~m}$ & Acropora & 92.8 & 167.131 & 2.058 & 3.4239 & 0.0047 & 2.013 & 0.004 & 50.8 & 0.003 & 4735.24 & 17.96 & 5216.81 & 14.9 & 0.8962 & 0.0012 & 1.131 & 0.004 & 1.21 & 0.005 \\
\hline Puhia 3, $-6.50 \mathrm{~m}$ & Acropora & 99.3 & 6.829 & 0.036 & 3.0164 & 0.005 & 3.937 & 0.013 & 3.439 & 0 & 56 & 0.74 & 24 & 9.19 & y & 0.0001 & .143 & 0.004 & 1.146 & 0.004 \\
\hline Puhia 3, $-9.75 \mathrm{~m}$ & Acropora & 97.2 & 8.046 & 0.117 & 2.8343 & 0.005 & 41.259 & 0.829 & 3.9019 & 0.0005 & 8 & 0.36 & & 4.24 & & 01 & 1.142 & & 1.146 & 0.004 \\
\hline Juhia $3,-12.75 n$ & Acropora & 99.1 & 8.697 & 0.051 & 2.9804 & 0.0019 & 12.875 & 0.116 & 4.327 & 0 & 62.87 & 0.6 & 707.88 & 6.43 & 0.0877 & 0.0001 & 1.146 & 0.003 & 1.149 & 0.003 \\
\hline Ome 1, $-0.10 \mathrm{~m}$ & Acropora & 99.5 & 2.620 & 0.01 & 2.6417 & 0.0028 & 1.085 & 0.001 & 1.179 & 0 & 69 & 0.77 & & 20.22 & 7 & 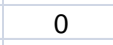 & 1.147 & 0.003 & 1.148 & 0.003 \\
\hline Ome $1,-5.20 \mathrm{~m}$ & Acropora? & 98.8 & 4.118 & 0.03 & 2.9616 & 0.0071 & 0.307 & 0.005 & 2.054 & .0005 & 1249.02 & 20.95 & 7.72 & 497.72 & 0.0419 & 0.0001 & 1.144 & 0.004 & 1.145 & 0.004 \\
\hline Ome $1,-10.25 n$ & Porites & 99.7 & 5.035 & 0.03 & 2.5139 & 0.0044 & 0.95 & 0.001 & 2.131 & 0 & 422.27 & 1.56 & 8141.75 & 23.96 & 0.0512 & 0.0001 & 1.147 & 0.004 & 1.149 & 0.004 \\
\hline Ome $2,-0.10 \mathrm{mF}$ & Pocillopora & 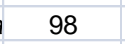 & 3.459 & 0.01 & 2.8329 & 0.003 & 311 & 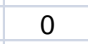 & 1.659 & 0 & 19.5 & 7.31 & 4 & 189 & & 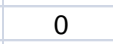 & 46 & 3 & 8 & .003 \\
\hline Ome 2, $-8.25 \mathrm{~m}$ & Acropora & 99.4 & 5.434 & 0.04 & 2.8249 & 0.009 & 0.292 & 0.005 & 2.5693 & 0.0004 & 1645.18 & 27.39 & 29566.73 & 500.3 & 49 & 0.0002 & & 0.005 & 1.145 & 0.005 \\
\hline Jme 2, $-20.75 \mathrm{r}$ & Acropora & 99.1 & 5.993 & 0.02 & 4.9707 & 0.0042 & 1.004 & 0.001 & 4.994 & 0 & 936.49 & 3.5 & 15235.19 & 39.09 & 0.0607 & 0.0001 & 1.147 & 0.003 & 1.15 & 0.003 \\
\hline Tofari & Acropora & 5 & 3.671 & 0.02 & 2.7444 & 0.0042 & 233 & 0 & 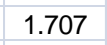 & 0 & & 13.7 & & 3 & & & 1.148 & 3 & 1.1 & 3 \\
\hline Tofari $1,-5.30 \mathrm{~m}$ & Acropora & 100 & 5.357 & 0.03 & 2.6807 & 0.0037 & 0.073 & 0.005 & 2.4017 & 0.0005 & & 421.13 & 111 & 7684.3 & & 01 & 1.142 & 0.004 & 1.144 & 0.004 \\
\hline Tofari $1,-9.75 \mathrm{~m}$ & Acropora & 94.9 & 6.849 & 0.03 & 3.2537 & 0.004 & 1.721 & 0.002 & 3.726 & 0 & 406.36 & 1.4 & 5800.98 & 13.25 & 0.0692 & 0.0001 & 1.148 & 0.003 & 1.15 & 0.003 \\
\hline Tofar & Acropora & .4 & 4. & 0.02 & 2.8058 & 36 & .259 & 0 & 2.221 & 0 & & 15.2 & & 30 & & & 1.14 & 3 & 1.1 & 0.003 \\
\hline Tofari 2, $-8.25 \mathrm{~m}$ & Acropora & 98.9 & 6.104 & 0.04 & 3.0803 & 0.0064 & 0.785 & 0.005 & 3.1513 & 0.0005 & & 5.14 & .37 & 84.99 & 0.0 & 0.0001 & 1.148 & 0.004 & 1.15 & 0.004 \\
\hline Tofari $2,-15.40 n$ & Acropora & 95.6 & 5.910 & 0.03 & 4.438 & 0.0061 & 3.81 & 0.007 & 4.407 & 0 & 216.67 & 0.77 & 3566.83 & 8.93 & 0.06 & 0.0001 & 1.147 & 0.004 & 1.15 & 0.004 \\
\hline $\pm 0 \mathrm{~m}$ & Acropora & 99.6 & & 0.02 & 3.8057 & 0.0042 & 206 & 0 & & 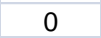 & & 34 & & & & & 1. & 3 & 1.152 & 0.003 \\
\hline Tofari 3, $-3.75 \mathrm{~m}$ & Acropora & 99.2 & 5.368 & 0.04 & 2.8779 & 0.009 & 0.123 & 0.005 & 2.5916 & 0.0005 & 3946.27 & 166.27 & 71631.62 & 3025.42 & 0.0544 & 0.0002 & 1.146 & 0.005 & 1.148 & 0.005 \\
\hline Tofari 3, $-7.20 \mathrm{~m}$ & Acropora & 97.3 & 6.332 & 0.03 & 2.7989 & 0.0037 & 0.664 & 0 & 2.966 & 0 & 843.46 & 3.66 & 13010.03 & 45.86 & 0.064 & 0.0001 & 1.147 & 0.004 & 1.15 & 0.004 \\
\hline
\end{tabular}

This article is protected by copyright. All rights reserved. 


\begin{tabular}{|c|c|c|c|c|c|c|c|c|c|c|c|c|c|}
\hline \multirow{3}{*}{ sample } & \multirow{3}{*}{$\begin{array}{c}\text { material } \\
\text { coral }\end{array}$} & \multirow{3}{*}{$\begin{array}{l}\text { Age } \\
\text { ky }\end{array}$} & \multirow{3}{*}{$\begin{array}{c} \pm \\
\text { ky }\end{array}$} & depth in core & e recovery & \multicolumn{5}{|c|}{ corr. core errorwater depthJepth below SL error } & $\min$. & \multicolumn{2}{|c|}{ orr. depth below Slaccretion } \\
\hline & & & & $\mathbf{m}$ & in barrel $(\mathbf{m})$ & )depth (m) & $\pm \mathbf{m}$ & $\mathbf{m}$ & $\mathbf{m}$ & $\pm \mathrm{m}:$ & ubsidence & min. subsidence & rate \\
\hline & & & & & & & & & & & $\mathbf{m}$ & $0,05 \mathrm{~m} / \mathrm{kyr}$ & $\mathbf{m} / \mathbf{k y r}$ \\
\hline \multicolumn{14}{|c|}{ HOLOCENE FRINGING REEF } \\
\hline Puhia 1, barrel 1 & Acropora & 5.116 & \#\#\# & -0.1 & 0.78 & -0.55 & 0.4 & -0.3 & -0.85 & 0.4 & -0.26 & -1.11 & 0.74 \\
\hline Puhia 1, barrel 2 & Acropora & 7.356 & \#\#\# & -2 & 1.33 & -2.09 & 0.1 & -0.3 & -2.39 & 0.1 & -0.37 & -2.76 & 5.82 \\
\hline Puhia 1, barrel 3 & Docillopora & 7.607 & \#\#\# & -3.4 & 0.82 & -3.54 & 0.3 & -0.3 & -3.84 & 0.3 & -0.38 & -4.22 & \\
\hline Puhia 2, barrel 1 & Acropora & 4.661 & \#\#\# & -0.75 & 0.25 & -0.81 & 0.6 & -0.6 & -1.41 & 0.6 & -0.23 & -1.64 & 1.48 \\
\hline Puhia 2, barrel 4 & Acropora? & 7.554 & \#\#\# & -4.75 & 1.12 & -4.94 & 0.2 & -0.6 & -5.54 & 0.2 & -0.38 & -5.92 & 3.67 \\
\hline Puhia 2, barrel 6 & Acropora? & 8.374 & \#\#\# & -7.5 & 0.98 & -7.91 & 0.3 & -0.6 & -8.51 & 0.3 & -0.42 & -8.93 & \\
\hline Puhia 3, barrel 5 & Acropora & 6.829 & \#\#\# & -6.5 & 0.36 & -6.84 & 0.6 & -0.6 & -7.44 & 0.6 & -0.34 & -7.78 & 2.44 \\
\hline Puhia 3, barrel 7 & Acropora & 8.046 & \#\#\# & -9.25 & 0.5 & -9.75 & 0.5 & -0.6 & -10.35 & 0.5 & -0.40 & -10.75 & 4.59 \\
\hline \multirow[t]{2}{*}{ Puhia 3, barrel 9} & Acropora & 8.697 & \#\#\# & -12.75 & 0.42 & -12.71 & 0.5 & -0.6 & -13.31 & 0.5 & -0.43 & -13.74 & \\
\hline & & & & & & & & & & & & mean & 3.12 \\
\hline \multicolumn{14}{|c|}{ PLEISTOCENE FRINGING REEF } \\
\hline Puhia 1, barrel 3 & Porites & \#\#\#\#\# & \#\#\# & -3.75 & 0.82 & -3.81 & 0.3 & -0.3 & -4.11 & 0.3 & & & 2.41 \\
\hline Puhia 1, barrel 7 & coral & \#\#\#\#\# & \#\#\# & -9.2 & 0.93 & -9.47 & 0.3 & -0.3 & -9.77 & 0.3 & & & \\
\hline Puhia 2, barrel 6 & Acropora & \#\#\#\#\# & \#\#\# & -8 & 0.98 & -8.14 & 0.3 & -0.6 & -8.74 & 0.3 & & & \\
\hline \multirow[t]{2}{*}{ Puhia 2, barrel 7} & Acropora & \#\#\#\#\# & \#\#\# & -9.5 & 0.77 & -9.77 & 0.4 & -0.6 & -10.37 & 0.4 & & & \\
\hline & & & & & & & & & & & & mean & 2.41 \\
\hline \multicolumn{14}{|c|}{ BARRIER REEF CORES } \\
\hline Ome 1, barrel 1 & Acropora & 2.620 & \#\#\# & -0.1 & 1.42 & -0.23 & 0.1 & 0 & -0.23 & 0.1 & -0.13 & -0.36 & 3.32 \\
\hline Ome 1, barrel 4 & Acropora? & 4.118 & \#\#\# & -4.8 & 0.7 & -5.2 & 0.4 & 0 & -5.2 & 0.4 & -0.21 & -5.41 & 5.07 \\
\hline Ome 1, barrel 7 & Porites & 5.035 & \#\#\# & -10.25 & 0.41 & -9.85 & 0.6 & 0 & -9.85 & 0.6 & -0.25 & -10.10 & \\
\hline Ome 2, barrel 1 & Pocillopora & 3.459 & \#\#\# & -0.1 & 0.65 & -0.68 & 0.4 & 0 & -0.68 & 0.4 & -0.17 & -0.85 & 3.84 \\
\hline Ome 2, barrel 6 & Acropora & 5.434 & \#\#\# & -7.75 & 0.48 & -8.26 & 0.5 & 0 & -8.26 & 0.5 & -0.27 & -8.53 & 20.36 \\
\hline Ome 2, barrel 13- & Acropora & 5.993 & \#\#\# & -20.75 & 0.27 & -19.64 & 1.4 & 0 & -19.64 & 1.4 & -0.30 & -19.94 & \\
\hline Tofari 1, barrel 1 & Acropora & 3.671 & \#\#\# & 0 & 0.6 & -0.45 & 0.5 & 1 & 0.55 & 0.5 & -0.18 & 0.37 & 2.87 \\
\hline Tofari 1, barrel 4 & Acropora & 5.357 & \#\#\# & -4.65 & 0.33 & -5.29 & 0.5 & 1 & -4.29 & 0.5 & -0.27 & -4.56 & 2.99 \\
\hline Tofari 1, barrel 7 & Acropora & 6.849 & \#\#\# & -9.75 & 0.11 & -9.75 & 0.6 & 1 & -8.75 & 0.6 & -0.34 & -9.09 & \\
\hline Tofari 2, barrel 1 & Acropora & 4.693 & \#\#\# & 0 & 0.8 & -0.43 & 0.4 & -0.45 & -0.88 & 0.4 & -0.23 & -1.11 & 5.31 \\
\hline Tofari 2, barrel 6 & Acropora & 6.104 & \#\#\# & -7.62 & 0.22 & -8.26 & 0.6 & -0.45 & -8.71 & 0.6 & -0.31 & -9.02 & \\
\hline Tofari 2, barrel 11 & Acropora & 5.910 & \#\#\# & -15.4 & 0.14 & -15.75 & 0.7 & -0.45 & -16.2 & 0.7 & -0.30 & -16.50 & \\
\hline Tofari 3, barrel 1 & Acropora & 5.168 & \#\#\# & 0 & 0.55 & -0.48 & 0.5 & 0.4 & -0.08 & 0.5 & -0.26 & -0.34 & 16.3 \\
\hline Tofari 3, barrel 3 & Acropora & 5.368 & \#\#\# & -3.2 & 0.42 & -3.74 & 0.5 & 0.4 & -3.34 & 0.5 & -0.27 & -3.61 & 3.12 \\
\hline \multirow[t]{2}{*}{ Tofari 3, barrel 5} & Acropora & 6.332 & \#\#\# & -7.2 & 0.13 & -6.75 & 0.7 & 0.4 & -6.35 & 0.7 & -0.32 & -6.67 & \\
\hline & & & & & & & & & & & & mean & 7.02 \\
\hline
\end{tabular}

This article is protected by copyright. All rights reserved. 


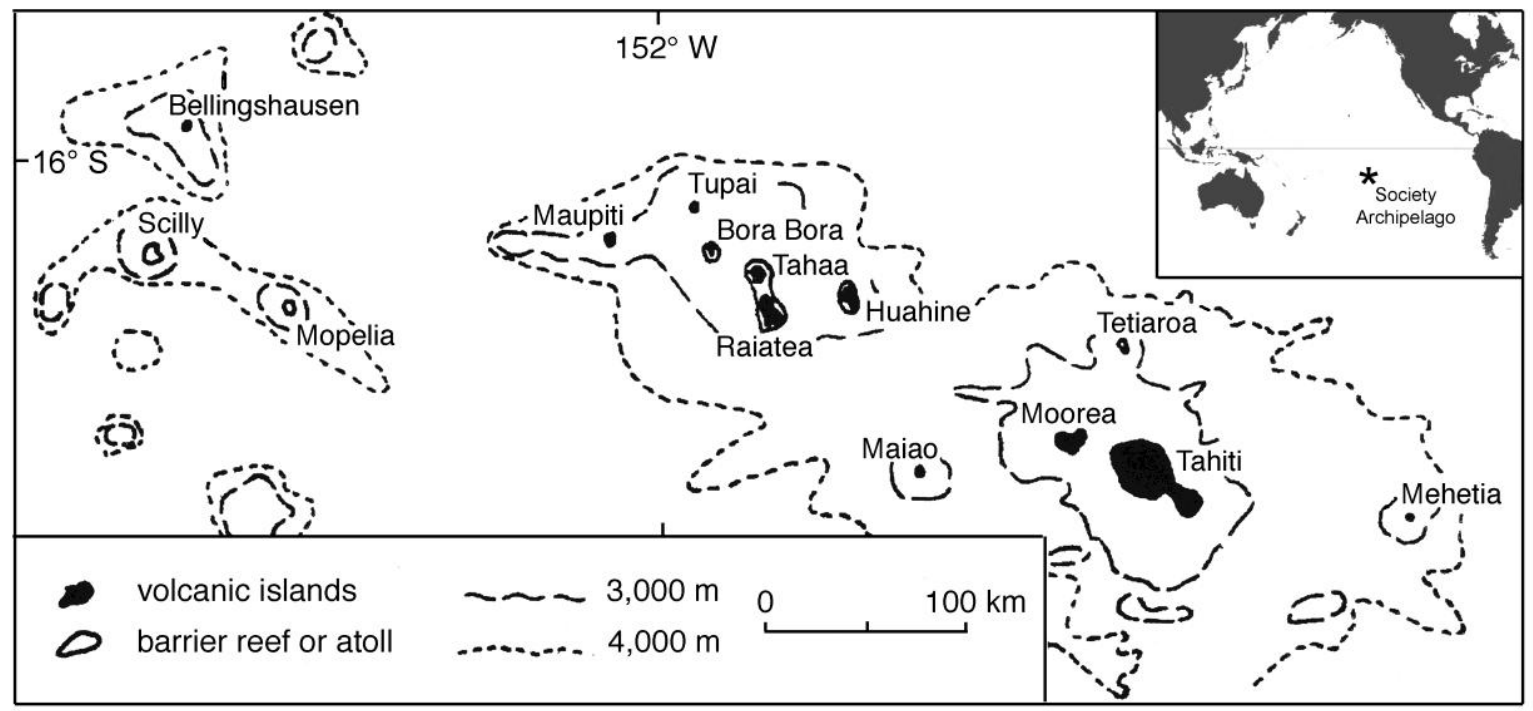

This article is protected by copyright. All rights reserved. 


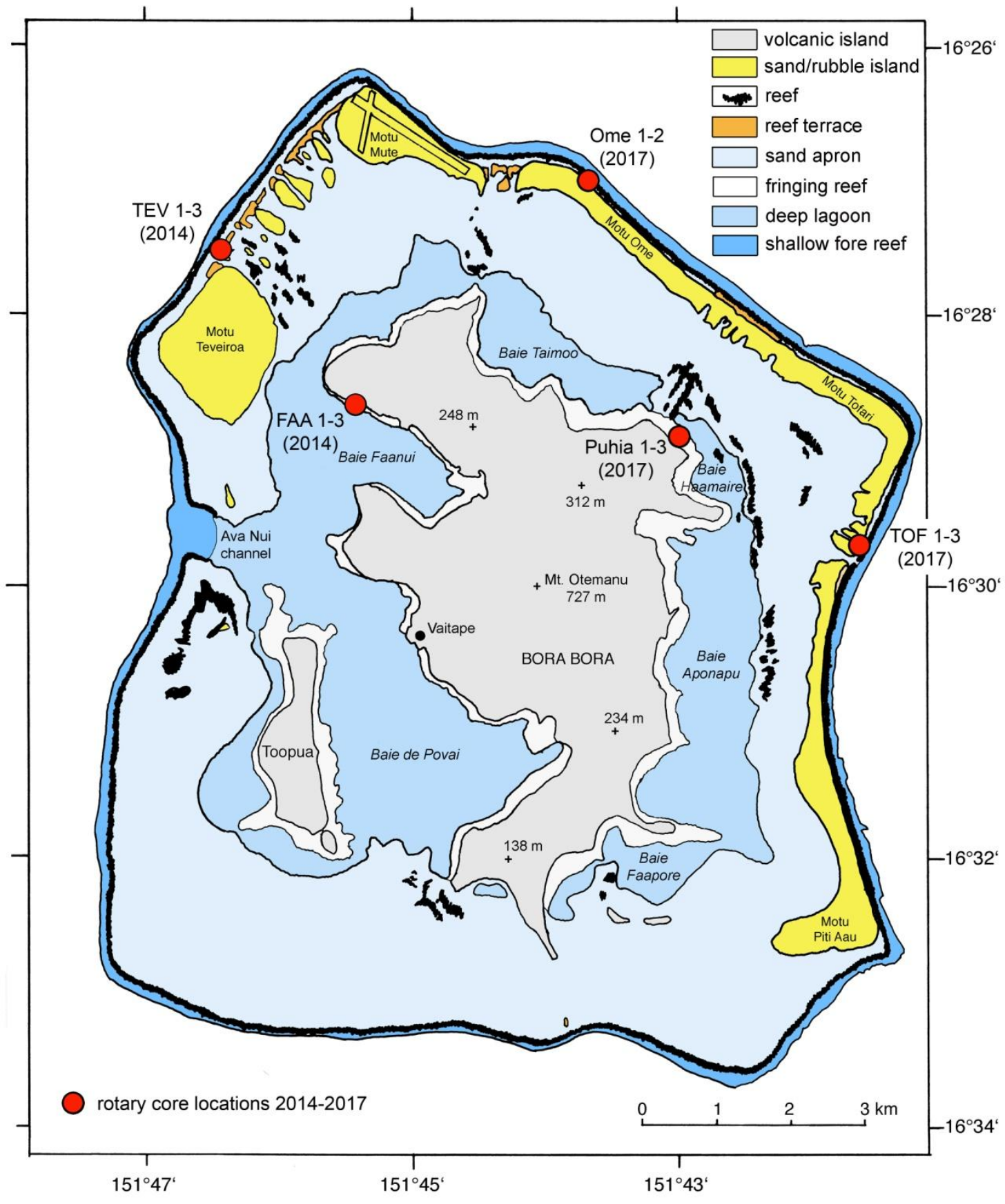

This article is protected by copyright. All rights reserved. 


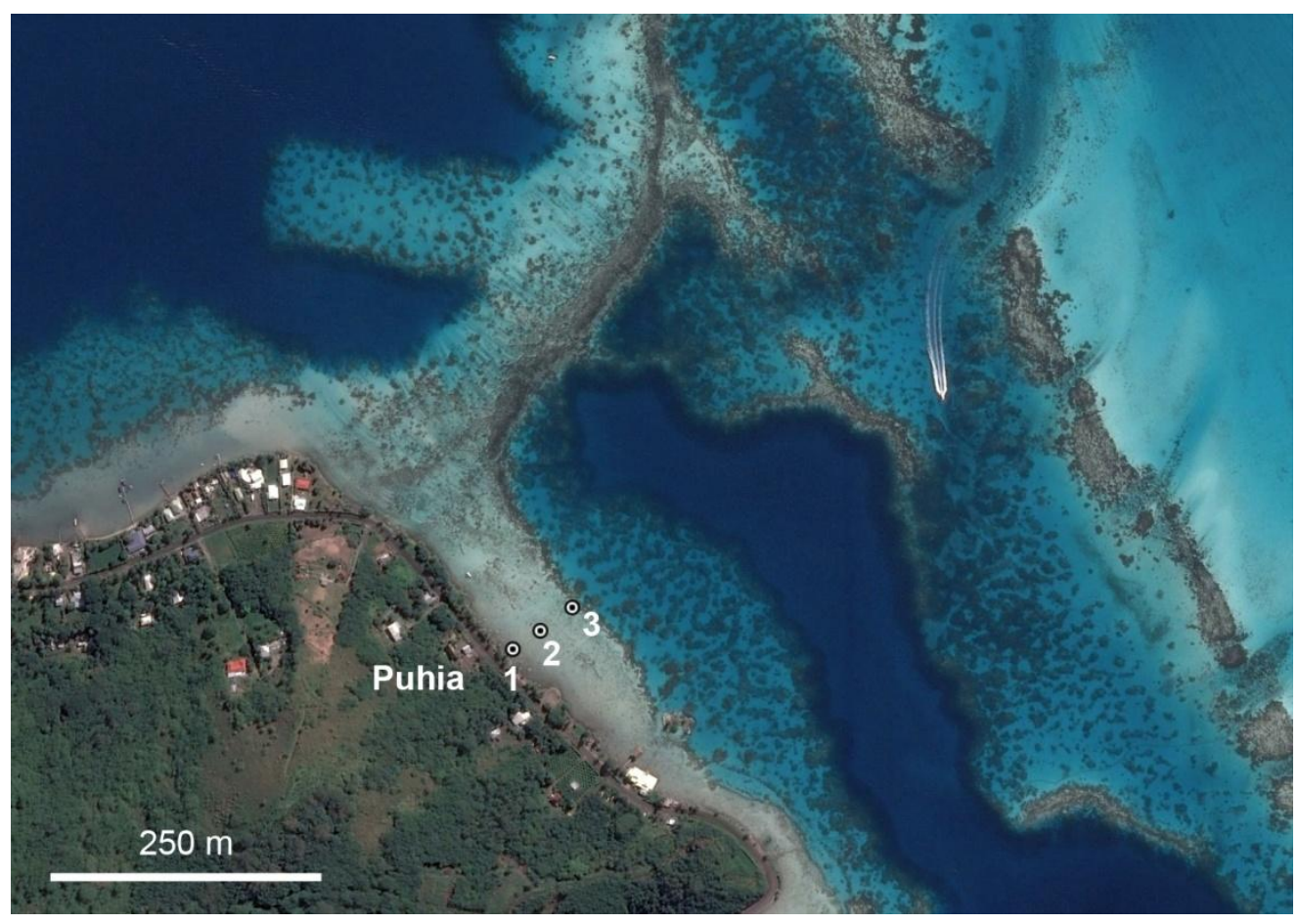

This article is protected by copyright. All rights reserved. 


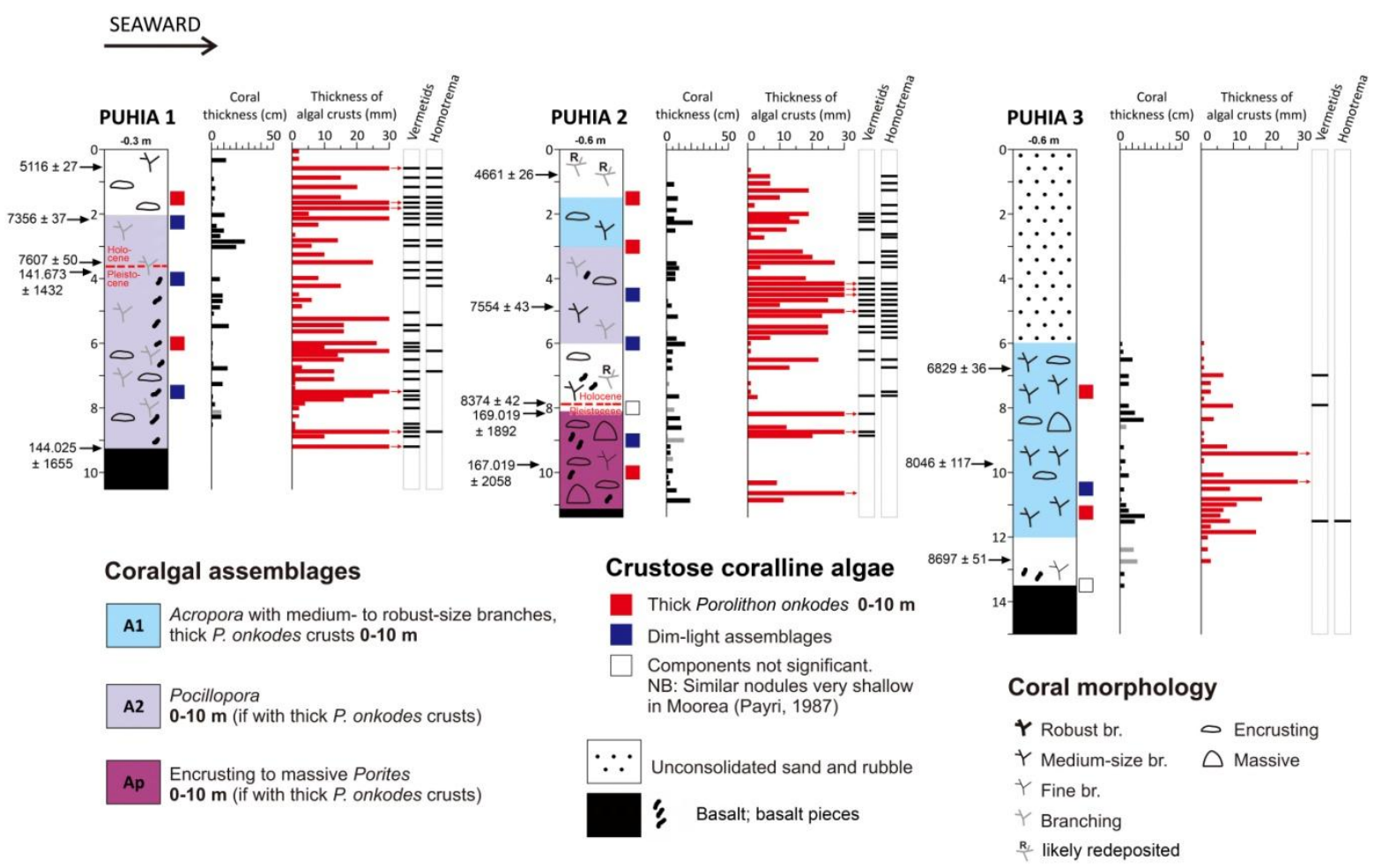

This article is protected by copyright. All rights reserved. 

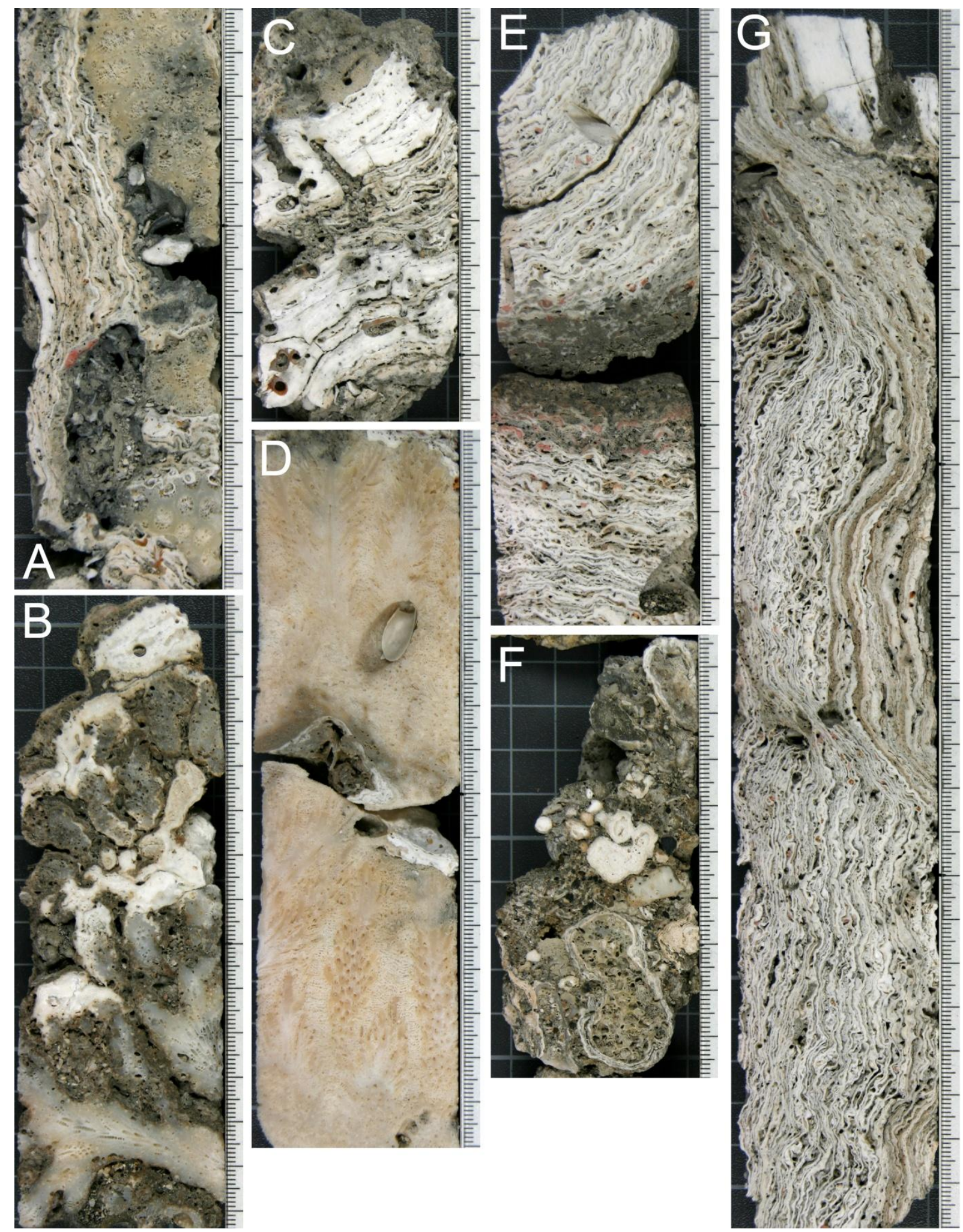

This article is protected by copyright. All rights reserved. 

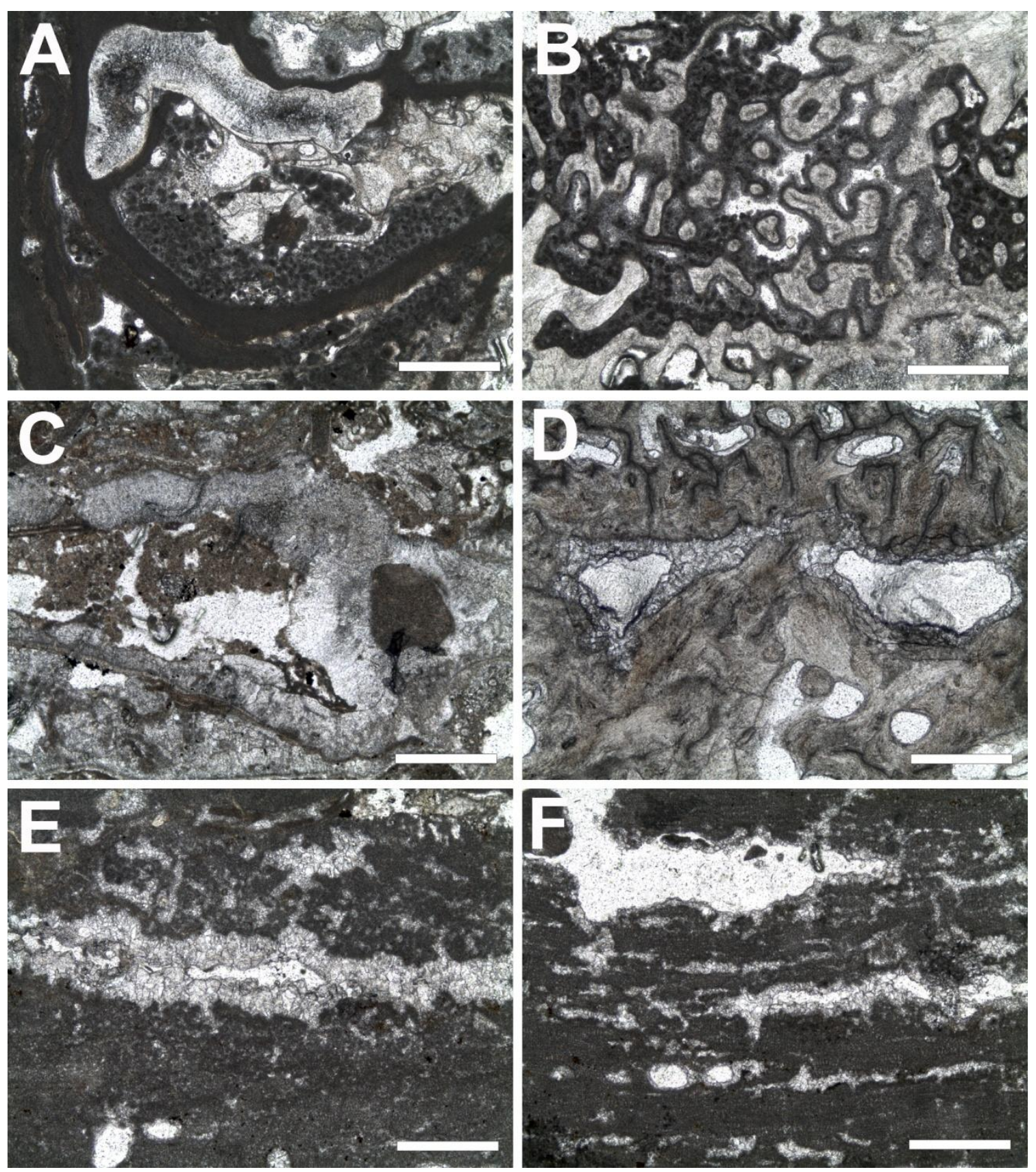

This article is protected by copyright. All rights reserved. 

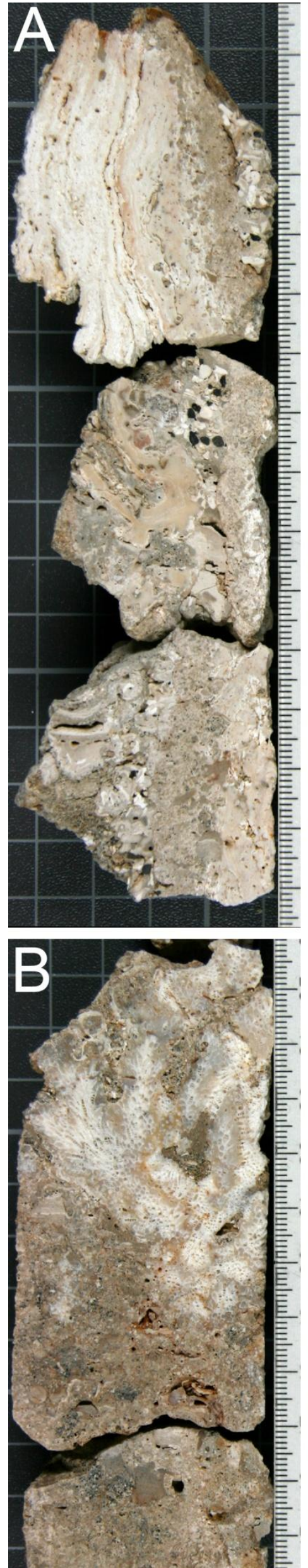

This article is protected by copyright. All rights reserved.
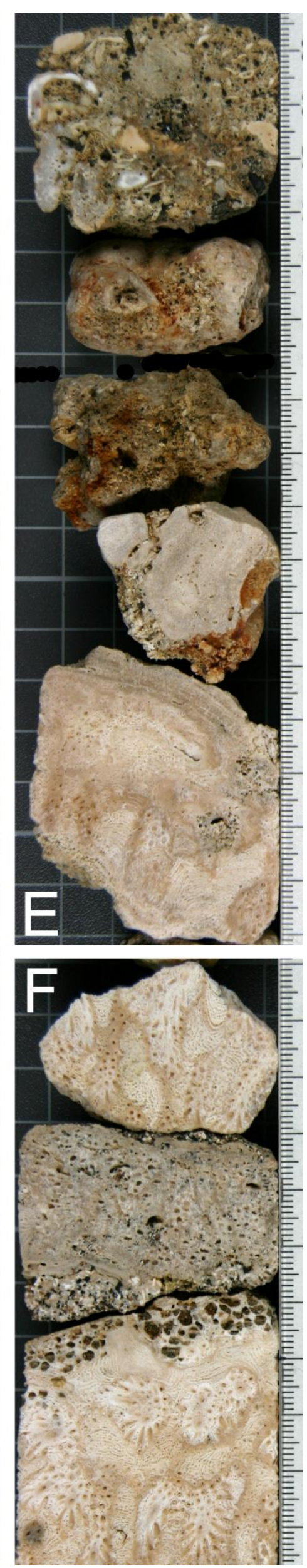

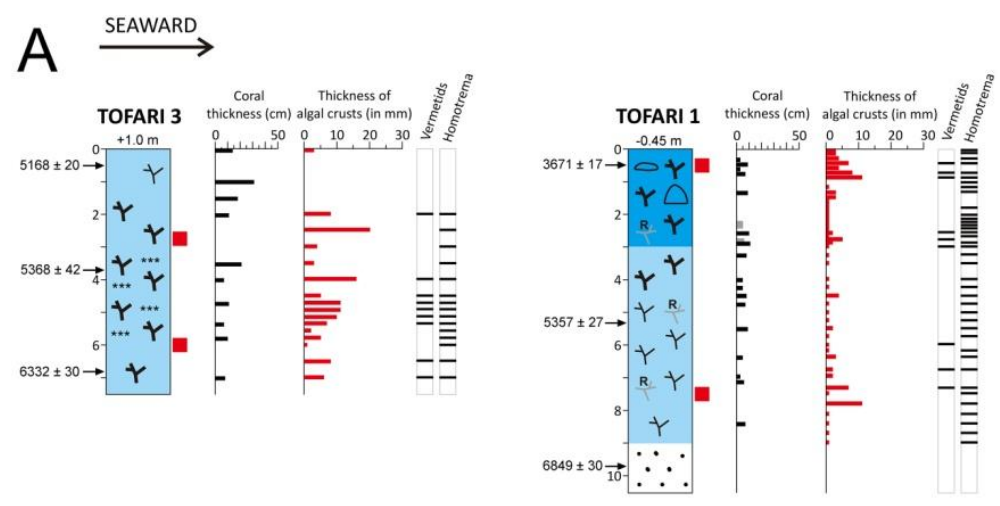

B $\stackrel{\text { SEAWARD }}{\longrightarrow}$

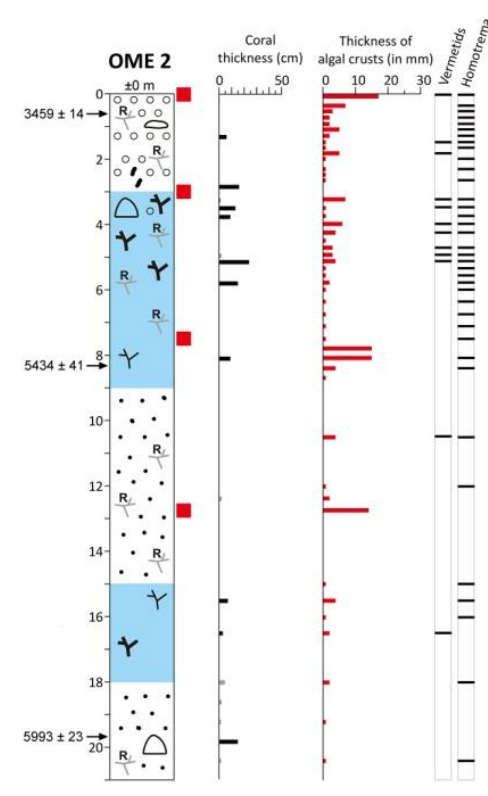

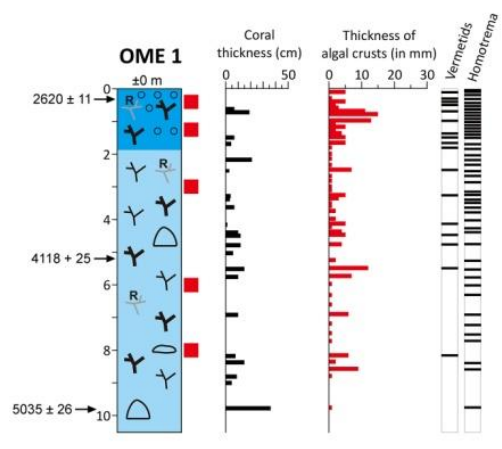

Crustose coralline algae

- Thick Porolithon onkodes $\mathbf{0 - 1 0} \mathrm{m}$

$\because$ Unconsolidated sand and rubble

$\because 0$ Rudstone

... Microbialite

" Basalt pieces

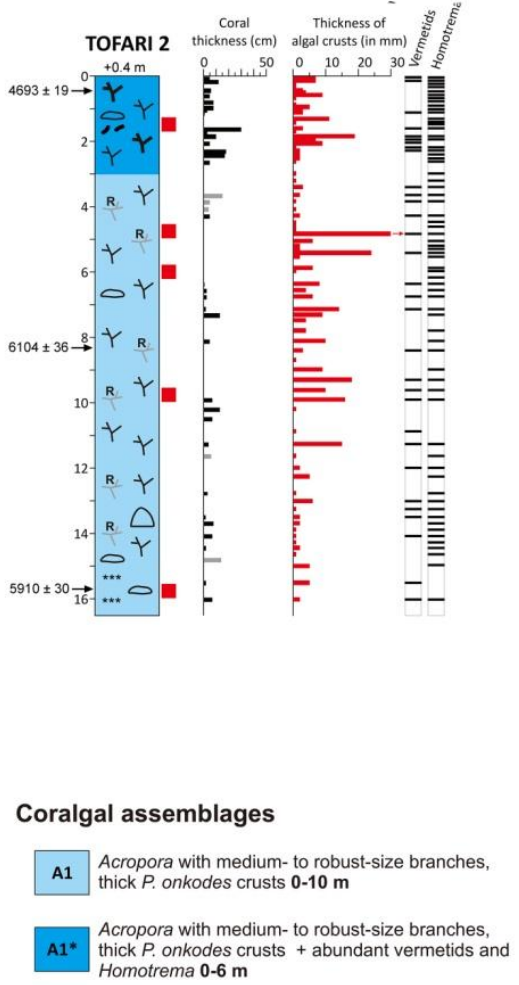

Coral morphology

$\uparrow$ Robust br. $\quad$ Encrusting

$\uparrow$ Medium-size br. $\triangle$ Massive

$\nsucc$ Fine br.

$\nsucc$ Branching

R likely redeposited 


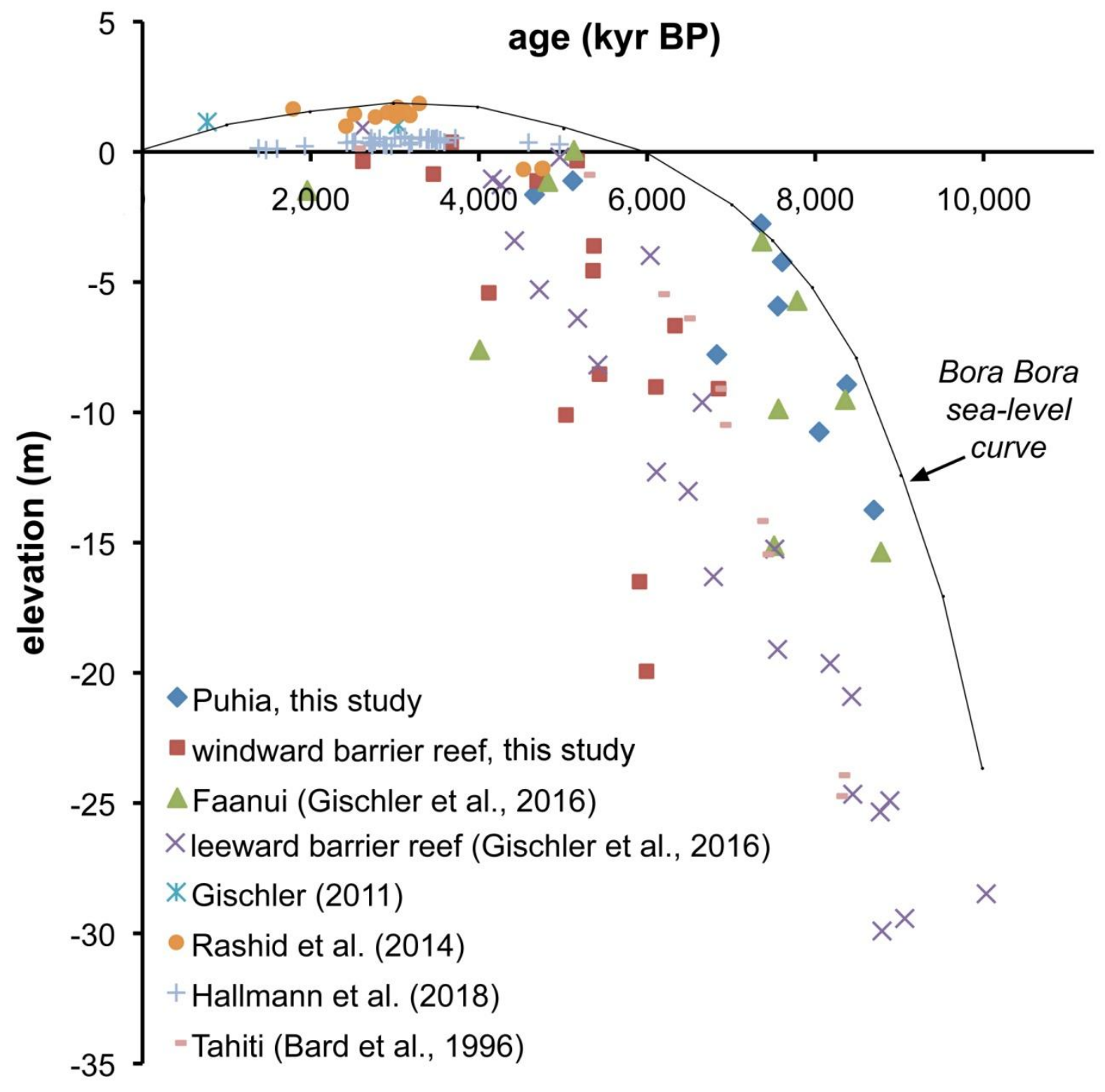

This article is protected by copyright. All rights reserved. 

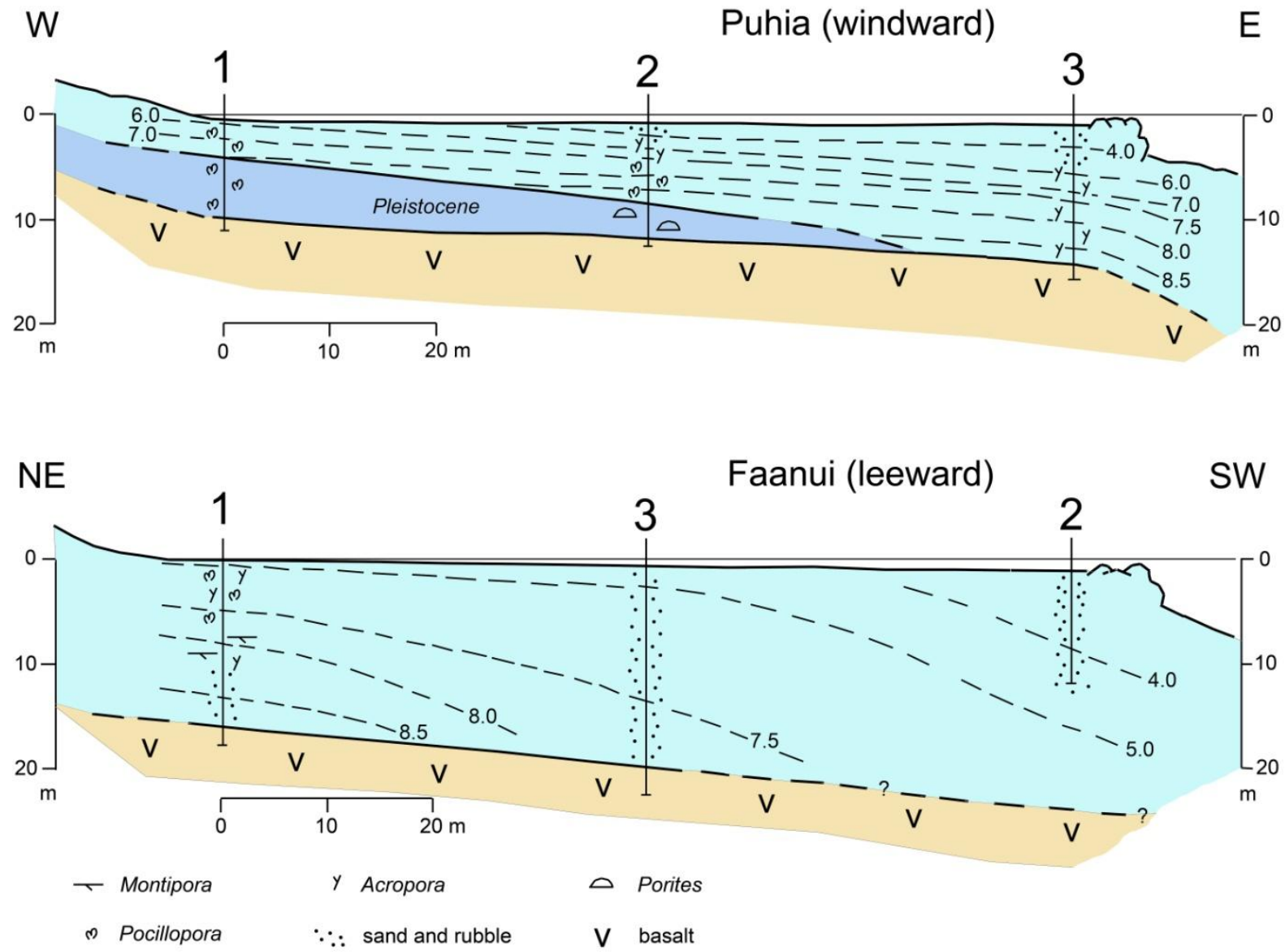

This article is protected by copyright. All rights reserved. 